\title{
The Dutch Reformed Church and the Faculty of Theology at the University of Pretoria
}

Author:

Philippus R. du Toit ${ }^{1}$

\section{Affiliation:}

${ }^{1}$ Department of Church

History and Church Polity,

University of Pretoria,

South Africa

\section{Correspondence to:}

Philippus du Toit

e-mail:

ngkerk@postino.up.ac.za

Postal address:

PO Box 12100, Hatfield,

0028, South Africa

\section{Keywords:}

Dutch Reformed Church

Faculty of Theology;

University of Pretoria;

heresy; Pretoria

\section{Dates:}

Received: 06 July 2009

Accepted: 17 Aug. 2009

Published: 17 Dec. 2009

How to cite this article:

Du Toit, P.R., 2009, 'The

Dutch Reformed Church

and the Faculty of Theology

at the University of

Pretoria', Verbum et Ecclesia

30(3), Art. \#263, 18 pages.

DOI: $10.4102 /$ ve.v30i3.263

This article is available at:

http://www.ve.org.za
(C) 2009. The Authors. Licensee: OpenJournals Publishing. This work is licensed under the Creative Commons Attribution License.

\section{ABSTRACT}

The focus of this article is on the fundamental and practical reasons that led to the establishment of theological training by the Dutch Reformed Church in the northern part of South Africa. The Faculty of Theology (Division B) was eventually established in 1938 at the University of Pretoria nearly 80 years since the opening of the Theological Seminary in Stellenbosch. Attention is given both to the major role players in Church and Faculty as well as to the developments that influenced both Church and Faculty: the Dutch Reformed Church of Transvaal eventually dissolved into four synods; the Faculty of Theology on the other hand united the two Divisions to become one multi-denominational faculty in 2000. Cognisance is taken of the major tensions between faculty and Church during the course of time. Special attention is given to certain accusations regarding theological heresy during the last decade.

\section{INTRODUCTION}

The establishment of the Faculty of Theology

The importance of theological training for the DRC

The fact that the Dutch Reformed Church (DRC) only started its theological training at the University of Pretoria 30 years after the establishment of the University should not be seen as an indication of indifference towards theological training as such. On the contrary, the importance of theological training for the DRC is quite evident when considering the facts.

After a period of 170 years as a church in the Cape Colony, the first synod meeting was held in 1824 . This was the first true synodal meeting on South African soil. At this very first synod the preliminary steps were taken towards the establishment of the Theological Seminary that began in Stellenbosch in 1859.

The establishment of the Seminary in 1859 can be considered a major turning point regarding theological training. However, shortly afterwards, a situation with serious consequences for the entire DRC arose. The unity between congregations to the north and south of the Orange River was shattered by the well-known Loedolff case (1861). This eventually led to the formation of separate DRCs in the Transvaal (DRCT), Natal and Free State. However, the various Churches continued to send all their students to Stellenbosch for training. The Seminary was regarded as the one visible sign of unity between the congregations.

This young institution developed and stayed independent at Stellenbosch in spite of the development of the Victoria College, which eventually became Stellenbosch University. Therefore, with the establishment of the Transvaal University College (later the University of Pretoria) in 1908, the Seminary had already fulfilled an important need despite the fact that it was not even 50 years old. The great developments in the north of the country also warranted attention on a theological level.

\section{The reasons for Pretoria in particular}

When focusing on the reasons for establishing theological training in Pretoria, the following should be taken into consideration:

\section{Unique demands}

The unique situation in the Transvaal should be taken into consideration. The advocates for an own faculty in Pretoria were heard long before the so-called Du Plessis case started in Stellenbosch. In Transvaal the demographic factors were very important; in those years more and more people relocated there. This occurred due to, among other factors, the expansion of the public service, mines and industry (Kerkbode 27.4.1922:547).

\section{Finances}

Establishing an independent seminary would have entailed major financial strain. Therefore the focus was on the possibility of becoming part of a university. However, this reason should be seen in the context of the fundamental argument, explained below.

\section{Fundamental argument}

The fundamental argument should never be underestimated when considering the establishment of theological training at the University of Pretoria (UP). In this regard the decisive role of someone such as Prof. D.F. du Toit Malherbe should be taken into account (Nicol 1946:7). He was a physicist who was recruited by General Jan Smuts to lecture at UP and as such he was one of the first four lecturers at the University and also one of the first that lectured in Afrikaans (Van der Watt 2008:12, 36). He was one of the lobbyists, together with Dr W.P. de Villiers (Department of German), that tried to persuade the DRC synod of Transvaal to establish a theological Faculty at UP. Although this request was unsuccessful, Malherbe did not give up. He was actively involved with the establishment of the 
men's residence Sonop in 1916. According to the acts of the 1916 synod he and De Villiers asked the synod to become involved in such a residence. The synod purchased a house and premises upon which Sonop would be established (Acta 1916:224; Kerkbode 15.6.1916:580). Sonop was well known over many years as a residence under supervision of the DRC. Residents were accepted from all faculties; however, it was especially known as a residence for theological students.

In 1922 Malherbe argued the case for a theological faculty in a letter published in Die Kerkbode, the official DRC newspaper. He did this on account of a draft resolution (by Rev. Paul Nel) to be discussed by the Transvaal synod later that year. In a follow-up letter he expanded on his reasons and discussed the demographic factors in depth (Kerkbode 30.3.1922:411, 27.4.1922:547).

Malherbe was an active member of the Pretoria East congregation. He did not only act as speaker when one minister left the service (Kerkbode 25.04.1934:754), but was also one of the delegates to attend the important synod in 1934 where they decided to appoint a commission to work towards the establishment of a theological Seminary for the DRC (Kerkbode 6.6.1934:1037; Acts 1934:4). Later that same year he expressed his views in another letter to Die Kerkbode (6.6.1934:1046-1048). This letter is very important because it provides a thorough explanation of the fundamental reasons for a theological faculty as part of a university (This quotation - as are the rest - was written in Afrikaans and is given in translated form):

For many readers of Die Kerkbode (especially in other provinces) the resolution adopted by the Transvaal synod regarding the training of ministers in Pretoria might be a shock. As someone that was involved with the establishment of the (Theological) Faculty in 1916 (when I have been in Church service for several years) and as one for whom the interests of the Church and the Kingdom are paramount, I want to explain the facts and concerns as I see them. Thus it might bring clarity to the matter. The reader will find the full resolution of the synod that was taken almost unanimously (175-5) somewhere else (see Kerkbode, 25 April, p. 746), and will also receive the official report in the section of the magazine reserved for the Transvaal. It will be clear to everyone that synod believes in the idiom Festina lente, that the Church in Transvaal does not want to rush things but to advance slowly and surely in order that the church public in the whole country can adjust to this new situation whereby the Federated DRCs from Cape Point to the other side of the equator will have another seminary for the training of their spiritual leaders. Our Church must view this from the broad perspective and with a view to the future. The question should be answered as how this will influence the interests of the $D R C$ as a whole. It should be regarded as a sign of natural growth, of development, of expansion.

Theology, the Queen of the Sciences - From a young age it has been my conviction that a university without a theological faculty or a seminary associated with it is an absurdity. As a student at Stellenbosch I saw and personally experienced what the value of a Seminary is for the University (at that stage the Victoria College). As student at the old University of Martin Luther (HalleWittenberg) I experienced the beneficial influence that a theological faculty had, to a certain extent, on the staff and students. Even in Munich with its Roman Theological Faculty one couldn't escape the idea that a person will not live 'by bread alone'.

Here at the old TUC (Transvaal University College) I missed the religious element. When the College expanded during the years of the war in '14, '15, '16 and began to spread its wings, Faculties for Agriculture, Veterinary Science, Commerce etc. were established. A few of us approached the Minister of Education (now Senator F.S. Malan) and obtained his permission for the establishment of a Theological Faculty.

The Netherdutch Reformed Church of Africa (NRCA), at that stage, having already had such plans, seized the opportunity

1.He is referring to the faculty in which the Nederduitsch Hervormde Kerk van Afrika and the Presbyterian Church were involved. and $\mathrm{Dr}$ J.H. Greyvenstein was appointed the first professor. Later Dr Engelbrecht and Dr Gemser were also appointed. On behalf of the Presbyterian Church Dr MacMillan, who lectured on philosophy of religion, was appointed. The involvement of the NRCA safeguarded the establishment of a theological Faculty a fact that the University will certainly always remember. This will also be a guarantee for the NRCA that with any expansion in future they will receive their due part and at least keep their three chairs. The idea that one party should dominate should certainly be banned.

Due to the political situation in our Church during the years of the War and afterwards - even in 1922 when the eminent previous moderator Rev. Paul Nel introduced the issue at the synod - and later during the Church Struggle in the South (and perhaps even as the eminent Rev. A.J. Louw expressed it) due to the Stellenbosch complex of many of our (younger) ministers, the time was not always appropriate to take this important resolution. Presently the political and ecclesiastical differences are something of the past - at least in its acute and undesired presentation. Now the issue can be dealt with calmly and on merit. Synod therefore decided more or less unanimously that this issue cannot be stopped and that to postpone a decision would worsen matters.

What can be wrong with the seminary? It is obvious that this question would be asked. Answers will be different. The seminary had always produced excellent and highly qualified ministers and will keep on doing so. However, one may ask why so many of our students are going to Amsterdam, Princeton, Louisville, etc. - and even to Potchefstroom (Reformed Churches) and Pretoria (NRCA) - to study further.

The Seminary cannot confer a BD or DD degree and ministers from our Church (with its more or less 800000 members) that want to specialise in theology must go to institutions of other Churches (Reformed, NRCA, Presbyterian, Baptist, etc.) - take for example all the doctors in theology of our Church. Even the Reformed Church with its 52000 members and the NRCA with not even 60000 members are far better placed with their institutions where their ministers in SA can obtain a doctorate. The large DRC is at present in a far inferior position.

In all other subjects one can obtain the highest academic qualifications. Our students are not compelled to go overseas as was previously the case. There are only certain exceptions, to encounter the richness of knowledge that cannot be supplied by our country. It is most certainly the time to alter this.

The Reformed Church in Holland has established a seminary in Kampen in 1854 - only five years prior to our own seminary. They realised, however, the necessity of a theological Faculty and established one at the Free University of Amsterdam in 1879.

(Die Kerkbode 6.6.1934:1046-1048)

Malherbe continued to explain the situation in Scotland (where a Church with a similar number of members had several theological institutions), and the fact that smaller Churches such as the Reformed Churches and the NRCA have their own theological training. He ends the paragraph with the following sentence: 'The NH of G Kerk of (Tvl.) $)^{2}$ on its own has double the membership of the Reformed Churches and the NRCA with their two faculties combined'. (Kerkbode 6.6.1934:1047).

Malherbe, in the conclusion of his letter, referred to the important issue regarding the unity of the DRCs. He wrote:

Something that should be regarded as important is the unity of the Federated Churches. This, however, is a totally fictional danger that is mentioned. In no way can the establishment of another place of training for ministers endanger the unity. The word 'schism' is even used.

The establishment of a theological Faculty in Amsterdam did not endanger the unity of the Reformed Church. In Scotland, the four faculties of the 'Church of Scotland' and four seminaries 
of the 'United Free Church' did not loosen the ties, but have in fact caused more cooperation and eventually total unification in October 1929. Rev. P. du Toit mentioned that even the fact that the DRC in the sixties was divided into four different Churches did not endanger the true unity. Sharing joint magazines (Kerkbode, Koningsbode, Kindervriend, Jaarboek etc.) and having the same Afrikaans cultural background and the same ecclesiastical interests as well as the Federated Council of Churches, the ties are strong and secure. Not even a resolution of one of the synods or the expansion with the opportunities for theological training will influence this unity in the long run. By acknowledging each other's courses it will be possible for students to change from one institution to the other. This is commendable as this is also done in others fields of education. The calling of ministers that was educated at one institution to another part of the country will also help to solidify the unity.

The Church will have full responsibility regarding the doctrine and conduct of lecturers, in regard to their responsibility to prepare candidates for ministry and especially the Ecclesiastical Examination by the appropriate commission. The University, with its conscience clause, has nothing to do with this (the University prepares for and examines solely the $B D$ and $D D$ degrees). Given the experience in other countries and in $S A$ it will be a stipulation with the appointment of every theological lecturer that he can fill the chair only as long as he ascribes to the doctrine of the Church. This will preclude any dissident views.

Healthy competition will only benefit the Seminary of our Church. In future our offspring will smile about the present objections - in the same manner as we do now when we read the Acts of the Cape synod regarding the objections prior to the establishment of the seminary.

(Kerkbode 6.6.1934:1047-1048)

This viewpoint of Malherbe should be considered closely. It was indeed a very important issue: Should a theological faculty be part of the University or not? The example of the Netherlands had a profound influence on the discussion - especially the case of ordo simplex and ordo duplex. Ordo simplex entailed that a university appointed lecturers with funding by the state and that the government was responsible for supplying all the necessities for theological training. Ordo duplex, on the other hand, entailed that (in addition to certain lecturers being appointed by the University) the Church could also appoint lecturers who could attend to the more ecclesiastical subjects. In a memorial book celebrating 75 years of the existence of the Seminary at Stellenbosch (1934), the Rev. J. Rabie argued that the seminary should always be independent and that the Church should take full financial responsibility. Rabie was strongly opposed to the possibility that a theological faculty should be part of a university. He argued the case for the independence of the Seminary at Stellenbosch - a situation that eventually changed in 1963 when the Seminary changed to be the Faculty of Theology at the Stellenbosch University. Rabie had strong opinions in this regard:

As such a University makes a deal with a Church - not on behalf of the Church, but only with regards to its own advantage and given certain situations this 'own advantage' can be fatal for the Church.

(Rabie 1934:217)

In conjunction with this fundamental argument, the historical development that led to the establishment of the Faculty can now be discussed.

\section{The advocates for theological training in Pretoria}

Since the synod of 1916 there were advocates for theological training of the DRC at the University of Pretoria. At the 1919 synod there was a formal request from the University in this regard, but it was turned down. In 1922 there came a turning point when Rev. Paul Nel proposed a draft resolution in this regard. He was a prominent minister in the Transvaal, as well as moderator and the representative of the DRCT on the Board of Curators at the Seminary in Stellenbosch. ${ }^{3}$

It was customary at that stage for draft resolutions to be published in the official magazine of the Church, Die Kerkbode. Rev. Paul $\mathrm{Nel}$, in his draft resolution for the 1922 synod, proposed that there should be negotiations with the University of Pretoria in order to establish facilities for the training of ministers for the DRC.

When this draft resolution was published, the editor of Die Kerkbode, Rev. P.G.J. Meiring, deemed it necessary to react. He declared in an article in Die Kerkbode of 16 March 1922 that such a draft resolution had the possibility to lead to 'a separation by the Transvaal Church from the other Churches in regard to the training of ministers'. This gave rise to many letters in the following editions of the magazine, both by those in favour of and those opposed to the idea. Especially significant was the declaration by professors from the Seminary at Stellenbosch, namely P.G.J. de Vos, A. Moorrees, J. du Plessis, B.B. Keet and E.E. van Rooyen (as well as Rev. D.S. Botha, scribe of the Board of Curators and Moderator of the Cape DRC), published in the April edition of Die Kerkbode. In it they deemed this draft resolution to be 'intended to sever the ties between the Seminary and the DRC in Transvaal'. They added: 'We also want to warn that, however good the intentions might be - according to our considered opinion this can have disastrous consequences for our Church in South Africa' (Van der Watt 1987:172-173, ed. 1988:6).

Their objections against the proposed training in the Transvaal were, among others, that it would confirm the division that occurred within the DRC since the Loedolff case of 1862 (when the congregations to the north of the Orange River were legally barred from the synod in Cape Town). The ideal of eventual unification would thus be frustrated. It would only be a new cause for division and augment alienation. They also posed the question whether it would not be more fruitful to build a stronger seminary instead of establishing a few weaker theological faculties. Another question was what the consequences would be if the Church in the Free State would follow the example set by the northern synod (Kerkbode 20.4.1922:496-497; ed. Van der Watt 1988:6-7).

Rev. Paul Nel did not alter course. He argued his case with confidence at the 1922 synod. According to the minutes he used the following arguments: No politics were involved; it was not aimed against Stellenbosch - however, there might have been students in the Transvaal that could not go as far as Stellenbosch for their training; there would be no disruption of powers; this would only be a natural development in the totality of the Church; and the Church would still be responsible for the doctrine of the professors.

Those opposed to the idea also argued their point vigorously: It would weaken the ties between the four federated Churches; the Transvaal had received its fair share of those being trained at Stellenbosch; the government would have a say in the training of ministers in Pretoria. At the end, the resolution was rejected by a great majority. The training as well as the legitimisation of trained students was therefore reserved for the DRC in the Cape.

In those years some people other than Seminary students were allowed as ministers in the Transvaal; A Commission of Examiners existed. Their task was to test the following persons for ministry:

3. The historical facts presented here are mainly based on three articles. Except where otherwise indicated the facts are taken from Van der Watt 1987:170-183, 1988:5-19 othen and Borcharticle by Van . When certain facts from that article are referred to, it is done only to reiterate the current author's argument. 
1. Missionaries. They had to equip themselves by way of private studies. Having complied with the prescribed syllabus they could apply for examination. Several people gained entry to ministry in this way.

2. People of other denominations could also apply for examination and, having succeeded the Colloquium Doctum, were allowed to ministry.

Then there were those people who grew up as DRC members but, on account of the distance to Stellenbosch as well as the cost involved, were rather trained at Potchefstroom by the Reformed Churches in SA or at Pretoria by the NRCA. Some of these later applied, and were allowed, as ministers in the DRC.

As was already stated, the Transvaal synod of 1934 played an important role in the establishment of theological training in Pretoria.

In addition to the gradual development of the idea of theological training in Pretoria, the influence and consequences of the socalled Du Plessis case should not be underestimated. The Du Plessis case took place in the Cape DRC from 1928 to 1932. It involved Prof. J. du Plessis of the Seminary, who was accused of heterodoxy concerning the doctrine and was suspended by the synod although the presbytery found him innocent. Du Plessis eventually appealed to the Supreme Court, where his appeal succeeded in 1932. The synod, however, barred him from lecturing again although they granted him his salary.

The relationship between the DRCT and the Cape Church was strained. Except for the fact that Rev. Nel was an advocate for theological training in the north, he also represented the DRCT on the Board of Curators at Stellenbosch. As a curator Rev. Nel had let it be known that he was not satisfied with the way the Board of Curators had handled the case against Prof. Du Plessis. The synod in the Transvaal also appointed an own commission to study the possible heterodoxy of the professor (ed. Van der Watt 1988:8-9; for a longer summary of this case, see Van der Watt 1987:163-170).

Even before the synod of 1934 took place, the growth at the University of Pretoria required the serious attention of the Church. There was a steep increase in the number of students and the Church realised that it had an obligation to support the large number of its members at university. An own theological faculty would greatly assist in this regard. This reason was supplementary to what had taken place in 1925. At the 1925 synod a certain commission reported on how the Church could be represented more in higher education institutions in the Transvaal. This eventually led to a minister of religion (Dr D.J. Keet) being appointed on the Board of TUC. He could thus be regarded as an official representative of the Church. Therefore, although the synod did not approve the appointment of theological professors, this commission drew attention to the fact that the NRCA could muster great influence at the institution. There was also appreciation for the fact that the Pretoria congregation, having been a partner in the erection of the men's residence Sonop in 1916, had a positive influence at TUC on behalf of the DRC (Van der Watt 1987:173-174).

During the 1934 synod the training of ministers at the University of Pretoria took a distinctly positive turn. The influence of certain ministers cannot be discarded - people such as Rev. A.J. Louw, a previous moderator and at that stage Chancellor of the University of Pretoria (1933-1934), and Dr D.J. Keet, minister at the congregation of Pretoria East but also a member of the Board of the University.

There were draft resolutions asking the Church to negotiate with the University of Pretoria to establish a theological faculty for the 'Nederduits Hervormde of Gereformeerde Kerk van Zuid-Afrika', as the DRCT was known officially until 1957. After a very lively debate on the draft resolutions, a commission was appointed to investigate all possibilities. The final, adopted resolution stated the following:

The synod is certain that this is an issue that cannot be barred, namely that the Church must be more involved with the University of Pretoria. Delay in this case would only complicate matters. Consequently (the) synod decides to refer this to a commission to investigate and report to the following synod, especially for the following reasons.

1. The Church as a whole does not posses all the relevant information as does this meeting. A drastic decision could easily horrify people.

2. There is not much chance of acquiring the necessary funds immediately.

3. The Church in the Cape could easily misunderstand such a decision in the present circumstances.

(ed. Van der Watt 1988:9-10)

This commission consisted of the following members: Rev. W.M. Nicol as moderator, Rev. J.I. de Wet, Dr J.H. Eybers, Rev. Paul Nel, Rev. J.H.M. Stofberg, Rev. P. van der Hoven and Rev. G.D. Worst. This commission had a substantial task. They were commissioned to negotiate with the Church in the Cape regarding all aspects that involved the two Churches. There had to be no misunderstanding of each other that could endanger unity. Furthermore they had to seek the cooperation of the Churches in Natal and the Free State. The most important issue, however, was negotiations with the University of Pretoria regarding chairs and courses. Additionally the synod had to inform their own congregations regarding this resolution and to obtain the necessary funding. They also had to investigate the possibility of funding by the state.

A well-motivated document was compiled to be presented to the three 'sister Churches' in the Cape, Free State and Natal. Firstly complaints were addressed and secondly the motives of the synod were carefully stated.

The complaints were in connection with the following issues:

- The Du Plessis case. This was adequately answered by drawing attention to the fact that the idea was first mentioned in 1922 with the discussion of the draft resolution. At that stage Prof. Du Plessis still had everyone's trust.

- The fact that this would be a faculty. The cost of a seminary would be too much.

- The fear that there would be a surplus of qualified proponents. This issue was addressed by emphasising that the Great Depression (1932-1933) had passed and that a big expansion for the Church could be expected.

- The possibility of division within the Church. In this regard it was concluded that the Faculty would bring about a new cohesion between the federated Churches.

The motives of the synod could be summarised as follows:

- The DRC wished to obtain more influence at the University because there was an increase in Afrikaans-speaking students

- The DRCT was the only one of the four federated Churches that was in competition with the NRCA and the Reformed Church (and both of these Churches were giving theological training in Transvaal)

- Students of the DRC were being trained by other Churches and were, after completing a successful Colloquium Doctum, allowed to the ministry in the DRC

- The functional 'training' of ministers for the Transvaal had its unique difficulties: Industry, Blacks instead of Coloureds, and competitive Churches (ed. Van der Watt 1988:9).

Both Dr Nicol and Dr Eybers were sent to present the case at the Synodal Commission of the Cape Church. ${ }^{4}$ In the volume commemorating 75 years of the Seminary in 1934, Nicol (1934:198-204) expressed the opinion that the future was not

4.See Nicol 1958:323 for a detailed description. 
yet clear. 'It may happen that the Church in (the) Transvaal may soon determine to train its own ministers locally. If that happens, it will be for practical reasons.' According to him, these reasons were the following:

- Students had to get to know the situation in Transvaal and in the Church if they later wanted to minister there.

- More and more students were being trained at institutions of other Churches in Transvaal and then wanted to enter the ministry at the last minute and be eligible.

- The influence of theological students that could be exerted among the three to four thousand other students in Transvaal was indispensable. It is important that the same influence of theological students on other students had to be exerted as was the case in the Cape.

- Self-preservation was crucial. The other Churches were threatening to take over completely. Our Church needs to strengthen our situation.

(Nicol 1934:203)

In spite of all these arguments that were voiced - during visits, in reports and in the commemorative volume - the Cape Church's synod of 1936 was not sympathetic to the idea of a theological Faculty in the north. The synod answered:

Synod recognizes with true regret the proposed plan of the Transvaal Church to establish a theological Faculty whereby the fraternal bond may be broken. The synod earnestly appeal [sic] to the Church to reconsider its proposed plan.

(ed. Van der Watt 1988:9)

The Church in the Free State decided the following:

To say to the federated Church in the Transvaal that they must not expect any support, financially or morally from us. We however beg them to abandon the proposed plan.

(ed. Van der Watt 1988:9)

Only the Church in Natal was interested in this endeavour to establish theological training.

The Transvaal synod of 1934 commissioned the appointed commission to report on a regular basis to the Synodal Commission and to publish its report six months prior to the synod of 1937. The commission eventually held eight meetings and also met with representatives of other synods on occasion.

Another positive development prior to the 1937 synod was the fact that Prof. G.M. Pellissier, professor in Religious Studies at the University of Pretoria, was appointed in 1935 to attend meetings in an advisory capacity. This was a very important appointment for the DRC, especially since the Church at that time was exploring the possibility of establishing a theological faculty. The DRC approached the University and asked if they could propose a candidate for this position. The University appreciated this and thus Rev. G.M. Pellissier, a minister in the Carolina congregation at the time, was appointed. It is not easy to determine to what extent this appointment advanced the eventual establishment of a theological Faculty. It is clear, however, that Prof. Pellissier played an important role during the period 1935-1937 in the preparation for the Faculty.

The commission worked very hard and six months prior to the 1937 synod it published a report of almost 30 pages. The commission concluded this report with the following:

- A notable number of ministers and members of the federated Churches acknowledge the feasibility and importance of the establishment of a theological Faculty in Pretoria and we can count on their wholehearted support. Otherwise we are convinced that all the objections against the proposed plan in our Church as well as in the other provinces will disappear in the long run.

- Even if one or more of the synods of the federated Churches should decide not to cooperate, we are certain that there will be no alienation.

- Some of the Church councils did not receive adequate information regarding this issue because they did not have the opportunity to listen to Rev. Nel (organiser).
- Only with a few exceptions those Church councils that had objections agree on the feasibility and the necessity of the establishment, but they are of the opinion that it cannot be done because of the lack of funds.

- The present decision makers at the University are positive towards the establishment of a theological Faculty and therefore it is now the time to proceed. It is clear that more than $80 \%$ of the students at the University are members of the DRC. There are also 17 theological students of the DRC, some from the Free State. Consequently the Commission of Examiners will have candidates which they have to examine and approve for ministry for at least the next seven years - all of them enjoy training where the Church has no influence whatsoever. If the Church wants to continue with this endeavour, it is now the appropriate time.

(Van der Watt 1987:175-177; ed. 1988:10-11)

\section{The decisive synod of 1937}

Having drawn the abovementioned conclusions the commission advised the 1937 synod 'with the greatest confidence that the Church should now decide to meet the needs for the training of ministers at the University of Pretoria' (ed. Van der Watt 1988:11).

Because the chair of this appointed commission occupied the chair of the synod, the secretary of the commission, Rev. G.D. Worst, had to play a leading role. As the leading speaker he explained how several issues had led the commission to believe that it was the appropriate time to establish the theological faculty.

Among all the arguments that Rev. Worst made, it was partiularly the situation regarding probable theological students in the Transvaal that played a major role. These students could not, on account of the Depression, afford the travel and residence cost that study at Stellenbosch entailed. Consequently the Reformed Churches and NRCA, who had their own theological institutions in the Transvaal, accommodated these prospective ministers as students. In many instances these students were lost to the DRC.

Another fact in point was the small number of students from the Transvaal, in relation to the other provinces, that studied at Stellenbosch. At the theological Faculty in Pretoria there already was a student (S.J. Henrico) who underwent training in the NRCA and made himself available for calling within the DRC. He had to be examined regarding his doctrine and then be legitimised by the DRC. There was a real possibility that these cases would increase if the Church did not train its own ministers in the Transvaal.

The recommendation by the commission was supported by a petition from 20 students that already had commenced their studies in Pretoria. They requested that 'the door must not be closed in their faces'(ed. Van der Watt 1988:11), because they wished to complete their studies in Pretoria. This request, in the emotionally charged atmosphere, helped to create a more positive inclination towards the establishment of the Faculty.

Except for this request by the students, the commission had to provide very good reasons for those that were sympathetic towards the Seminary at Stellenbosch. The arguments regarding the unavailability of funds and 'the assertion that this Faculty would lean towards a liberal way of doing' (ed. Van der Watt 1988:11) had to be countered and solutions had to be provided.

Due to the lack of funds the commission recommended that a faculty should be established at the University and not a seminary. The cost to establish a full seminary would be too expensive. In the case of a theological faculty at the University of Pretoria the DRCT would only be responsible for a part of the salaries of the lecturers. 
The fear concerning 'liberal training' - when a professor at a university faculty could not be held accountable for his doctrine due to the conscience clause - was very real after the Du Plessis case. The commission, however, countered this fear by pointing out that in the agreement with the University provision was made to counter such a problem. Only lecturers that were recommended by the Church would be appointed. Moreover, the Church would enter into a contract with the lecturers whereby they could be fired if they should proclaim any heresy or be found guilty on any moral grounds.

Those that opposed a second training institution argued that the unity with the other Churches could be jeopardised. The commission remarked that the Presbyterian Churches in Scotland and America had more than one training institution. Those opposed to the second training institution regarded the surplus of students as a temporary situation. The accusation that those who sympathised with Prof. J. du Plessis of Stellenbosch, who had been discharged, saw this as an opportunity to establish an own Faculty was thoroughly refuted (Van der Watt 1987:177178, ed. 1988:11).

For all interested parties, including the first possible students, who followed the debate anxiously, there were three emotional highlights.

The first highlight was the speech by Prof. G.M. Pellissier. Although he had decided beforehand that he would not take part in the debate, he did join in when two delegates in their arguments referred to his person and position in the Faculty of Theology. He made a marvellous speech that carried great influence and altered the attitude of the synod towards the establishment of the theological faculty. He brought home the fact that the cultural struggle was not in the south of the country, but in the north. Because culture without religion is meaningless, a theological faculty for the Church at the University of Pretoria would be necessary to supplement the existing one. In this manner a true South African culture could be established, he said

He also stressed the fact that preliminary studies at the University of Pretoria could not be improved upon. The Church in Pretoria was confronted with issues that did not exist in rural Stellenbosch. In order for young ministers to investigate these social problems thoroughly, give worthwhile insight and have the appropriate attitude toward the people among whom they would shortly be working, the excellent undergraduate education in sociology provided by the University of Pretoria would be invaluable. This would enable young ministers to adapt, from the beginning, to the problems concerning industry, military service and public servants' special needs. Prof. Pellissier assured the synod that it did not need to worry that theological study will be influenced negatively, because 'if theology could not hold its own against the assault of science, it was of no value,' according to a report on the speech in The Pretoria News of 16 April 1937 (ed. Van der Watt 1988:12)

The second emotional highlight came on the Friday afternoon, 16 April 1937, after two full days of debating. At this stage the moderator determined that the synod was ready to vote. The elder of Malopo congregation and Rev. K.T. van den Heever, emeritus minister, led the synod in prayer. Then the members of the synod voted by standing. For both the supporters and the students it was an emotional moment of joy and thanksgiving when it was announced that the resolution was approved by 139 votes to 68. Everyone present was clearly aware of its historical importance when the announcement was made: 'The Church can now start to make provision for the training of ministers at the University of Pretoria' (ed. Van der Watt 1988:12).

The third emotional moment occurred during the evening session. Prof. Pellissier later recalled this as 'one of the nicest things that I ever experienced in my lifetime. This is a wonderful, glorious deed'. He referred to a declaration by the 68 members who voted against the proposal, presented by Rev. P. van den Hoven to synod. In this declaration they stated that they stood by their principles, but that they subjected themselves to the adopted resolution, and that they did it on behalf of 'our King and his Church'. Furthermore they stated that they had decided to do whatever they could, within their means, to advance the implementation of the synod's resolution. The synod was deeply touched by this and immediately thanked the Lord for this positive spirit (Van der Watt 1987:178; ed.1988:12; also see Nicol 1958:324)

With the resolution adopted, the implementation had to begin in earnest. Further negotiations with the University were entered into. This was done by the newly appointed commission for the theological Faculty. Prof. Pellissier asked the Council of the University to approve the synod's request to have a further three chairs and its own dean. This was adopted by the Council. As a member of a small commission of three Prof. Pellissier did his part regarding the drawing up of the contracts between the future lecturers and the University of Pretoria as well as regarding the by-laws describing their conduct and their relation with the Church. He and Rev. W. Nicol also attended to the remuneration and pension of the lecturers.

Dr D.J. Keet and Prof. Pellissier were requested to write a memorandum containing the requirements for the four chairs. They also had to compile a list of possible candidates, including their qualifications. This list had to be presented to the Theological Faculty commission, the synodal commission, the electoral college and the Council of the University prior to the professors being called.

On 9 December 1937 the Theological Faculty commission convened in the Voortrekker Memorial Hall in Pretoria. Following the prayer, the meeting convened, according to the Church Order, Article 183 11(2), as the electoral college to recommend the professors for appointment by the Council of the University of Pretoria. The chairperson determined that the meeting would take place in camera. Any candidates that were present also had to leave the meeting for the part that involved him

Prof. G.M. Pellissier was unanimously recommended as professor in Dogmatics and Religious Studies. For the other three departments people were selected from different panels: Dr E.P. Groenewald, MA DD, for the Department of New Testament Studies (the other person on the panel was Dr D.J. Keet); Dr D.J. Keet, BA DD, for the Department of Church History (the others on the panel were Drs J.J. Müller, G.B.A. Gerdener and J.H. Eybers); and Dr J.H. Kritzinger, MA DD, for the Department of Old Testament Studies (the other person on the panel was Rev. J.J. Odendaal) (Van der Watt 1987:178; ed. 1988:11-14).

\section{Division B established in 1938}

The South African government could not approve a second theological faculty at the same university. As the NRCA began with theological training in 1918 at the University of Pretoria, the problem was solved with the establishment of two divisions within the one Faculty of Theology: Division A for the NRCA and Division B for the DRC (Van der Watt 1987:178). Each division would have its own dean and its own lecturers for the various departments.

The recommended lecturers for the DRC accepted their appointments. Wednesday 16 March 1938 marked the beginning of theological training of the DRC at the University of Pretoria - 'a great day in the history of our Church in South Africa', (ed. Van der Watt 1988:13) according to Rev. A.F. Louw, one of the enthusiastic advocates of the Faculty.

During the morning the Examination Commission met the first six students who had already begun their classes on 1 February. They were J.P. Grobler, J.M. Louw, R.B.Murray, J.P. Theron, A.A. 
van Wyk and L.L.J. Visser. The secretary, Rev. A.J.V. Burger, said the following about this meeting:

With a great sense of thankfulness we shook their hands ... the first fruits! May they also be the first in knowledge, in devotion and in the service of the Lord.

(ed. Van der Watt 1988:13)

During the afternoon the Commission for the Faculty met in the Voortrekker Memorial Hall to finalise the ordainment of the professors.

That evening the Faculty of Theology (Division B) at the University of Pretoria became operational when the first four professors were ordained in the Pretoria East congregation amid great public interest. Rev. W.M. Nicol (chairperson) delivered a sermon on 2 Timothy 2:1-2, and the ordainment was done by Rev. G.D. Worst, secretary of the Commission for the Theological Faculty. Rev. Paul Nel Sr closed the ceremony with a prayer.

During the course of time, there were many lecturers that served the Faculty with great distinction. The following people served as deans: Profs G.M. Pellissier (1939-1945); D.J. Keet (1945-1948); E.P. Groenewald (1948-1970); H.D.A. du Toit (1970-1972); B.J. Marais (1972-1974); A.H. van Zijl (1974-1978); C.W.H. Boshoff (1978-1981); J.A. Heyns (1981-1984); A.B. du Toit (1984-1987); P.B. van der Watt (1987-1989); W.S. Prinsloo (1989-1996); C.J. Wethmar (1997-1999); and C.J.A. Vos (since 2000 in the multidenominational Faculty).

Since the establishment of Division B the Church in the north tried very hard to cooperate with the Cape Church regarding theological training. This only succeeded in 1945. Because the Natal Church gave its wholehearted support from the beginning, it was only the Free State Church that resisted cooperation. The Free State Church waited until 1951 to assure the synod in the Transvaal of its interest in the theological Faculty (Van der Watt 1987:180; ed. 1988:14)

\section{A multi-denominational faculty since 2000}

On 1 January 2000 the Theological Faculty at the University of Pretoria became a multi-denominational faculty, without the distinction between Division A and B. For the DRC this meant, inter alia, that it could no longer refer to the faculty as 'our faculty'.

The Church adapted to this new situation by acknowledging the fact that the dean was the head of the Faculty and was no longer in the service of one Church in particular. The Chairperson of the DRC's Council of Lecturers would in future be a member of the Board of Curators. The dean remained welcome to attend the meetings but was no longer obliged to take part

\section{Changes within the Church over the years}

The Dutch Reformed Church in the Transvaal (DRCT) had an interesting history and several name changes. During the thirties (when the theological training for the DRC commenced) the Church was officially known as the 'Nederduits Hervormde of Gereformeerde Kerk in Zuid-Afrika' - a legacy that dated from the 19th century when there was an amalgamation between the NRCA and the DRCT. Although the 'Nederduits Hervormde of Gereformeerde Kerk' disbanded after a few years, this name stuck as a name of the DRCT and was used until 1957. In that year the name was formally changed to the Dutch Reformed Church in the Transvaal (DRCT). In 1961 the DRCT divided into two synods: the Synod of Southern Transvaal and the Synod of Northern Transvaal - both synods, however, were still part of the DRCT. This was the situation when the General Synod of the DRC convened in Cape Town in 1962 when the general synodal cord between all DRCs was reinstated.

Since then the DRCT further expanded with the formation of the Synod of Western Transvaal and the Synod of Eastern Transvaal.
These four synods had a central administrative office in Pretoria, a central commission as well as a central archive.

At the beginning of the 21st century there was a strong urge to separate the four entities. This resulted in each synod running its own office. The archive was moved to Stellenbosch. At the moment theological training remains the only centralised activity in which all four synods participate. The DRCT remains a legal entity and the Combined Synodal Commission (CSC) acts as its one legal organ.

Coinciding with this streamlining of the DRCT into four separate entities, the Faculty began to operate on a much broader basis as a multi-denominational faculty. This fact in itself created problems regarding effective communication.

\section{Healthy interaction between Church and Faculty Students}

The students that are being trained at the theological Faculty are of paramount importance to the Church. Their training determines to a large extent what the Church will be like in future.

Since the beginning it was important that there should be enough students to justify this whole endeavour. Initially it appeared as if there would not be more than five students annually. This immediately raised the question whether standards should be lowered in order to attract more students. The lecturers, however, decided that the Church could only be served better by ensuring the quality of education.

A sound foundation in the basic theological subjects was (and still is) of great importance. This basic understanding was mentioned in the first report of the lecturers to the synod (1940):

The professors had long and endless discussions regarding the requirements for the preliminary study and are of the opinion that this should not easily be altered. It is to the advantage of the Faculty in future that the standards should be high-also during these difficult times and the difficult requirements that it entails. For the future minister the intellectual level cannot possibility be lowered - especially the preliminary studies. Exegesis of both the Old and the New Testament are of paramount importance. If there is only one subject in which future ministers should be well versed, it is exegesis of the Scripture.

(ed. Van der Watt 1988:15)

All along there was this focus on exegesis. It produced the necessary results. The young ministers were not only knowledgeable regarding exegesis but also held their own in the practice of practical theology, especially preaching. The positive influence of this on the life of the Church is immeasurable. It became clear that the special quality of the training of the students at the Faculty influenced more students to enrol.

The increase in student numbers was quite evident during the Faculty's first 50 years. In 1980 for instance no less than 98 students were legitimised.

The planning by the University for the physical needs lecturing halls, administrative and library facilities - provided the necessary space. Bursaries for students and the official involvement of the DRC provided the necessary steadfastness (ed. Van der Watt 1988:19).

The growth in the number of students declined during the last decade of the 20th century. The reason for this was the abundance of legitimised ministers for the few vacancies that existed. Thus only six students were legitimised in 2004. While the number of ordinary students declined, it is interesting to note that the number of people being legitimised after completing the Colloquium Doctum (re-entering ministry) began to grow 
and form an integral part of the statistics. ${ }^{5}$ This re-entering was made possible by General Synod accepting part-time ministers (Official Guard Book of the Board of Curators in Pretoria).

Since 2003 there was once again a steady increase in the numbers of new first-year students, averaging 40 students annually.

\section{The integrated course}

An important development in the theological training of the DRC was the introduction of the so-called integrated course - something that originated from the Theological Faculty in Pretoria.

Prof. A.H. van Zijl was the first to advocate the idea of an integrated course. He proposed a course in which subjects or parts of relevant subjects for future ministers would all be brought together.

Prof. Van Zijl wrote a memorandum explaining everything to the local Board of Curators, and after a positive response from them he was sent to Stellenbosch to present the idea there. The lecturers at Stellenbosch supported the idea. Prof. J.J. Müller immediately realised that this would mean that theological training could be completed in only six years. However, the Board of Curators at Stellenbosch did not support the idea.

This proposal was sent as a draft resolution to the General Synod of 1970 by both the Board of Curators in Pretoria and the Synodal Commission of Northern Transvaal. In neither 1970 nor in 1974 was this draft resolution approved by the General Synod. In 1978, however, the General Synod approved the idea of the integrated course. As a consequence theological training was shortened to six years. Those that had completed their study were obliged to take part in continuing theological training after serving a few years in ministry.

The adoption of this resolution meant that the two (later three) theological faculties together with the Board of Curators and the lecturers could plan the course. Equal - not similar - courses were planned. The draft resolution was adopted at the following General Synod (1982) and at the beginning of 1983 the first BA (Theol) students, whose course would only comprise six years, were enrolled at the Theological Faculty at the University of Pretoria (Van der Watt 1987:182-183; ed. 1988:19).

During the course of time, the integrated course has definitely revealed certain shortcomings. Those intimately involved with theological training are well aware of the situation. The Reformed Churches in South Africa were found not to be on par with the rest of the Reformed world concerning theological training, i.e. a sound philosophical and scientific foundation with a first degree, followed by theological study. Some of the young students are not properly equipped for theological issues at such a young age - they are often given answers to questions that they have not even contemplated. Another major problem is the fact that this integrated course is not conducive to specialisation: the study of the Biblical languages is usually not taken on postgraduate level. This results in a shortage of true specialists for the Biblical fields. The integrated course does not allow students to take philosophy at undergraduate level, not to mention post-graduate study. This leads to to a shortage of enough and well-grounded systematic theologians. Similarly the integrated course does not help to promote the study of Psychology and Sociology thus producing a shortage of specialists in practical theology. Likewise the lack of the study of History results in a shortage of specialists in Church History. It will be futile to rewind the clock with the present mindset of outcome-based education and return to the old model whereby students commence with their theological studies after the completion of a first (broader based) degree.

5.For example, in 199247 students and two Colloquia Docta were legitimised, in 1999 eight students and seven Colloquia Docta, and in 200715 students and six Colloquia Docta.

\section{Lecturers}

Lecturers within the Faculty have served the Church with their talents in a distinctive manner, and in different capacities: as true prophets, leaders, authors and poets.

The long and impressive list of well-known lecturers is not included in this article. It is an interesting fact that a wide variety of personalities were involved in the Faculty. This article does not intend to be complete in this regard.

The original small number of four lecturers steadily increased to 14 during the eighties. Since 2000 there was a decline and the number of lecturers stabilised at 10 . Since then one lecturer of the DRC was appointed by the University without the participation of the Church.

Not all of them can be named here, but Carel Boshoff, Dionne Crafford, A.B. du Toit, E.P. Groenewald, Johan Heyns, Dirk Human, Jurie le Roux, Ben Marais, Piet Meiring, Julian Müller, Malan Nel, Flip van der Watt, Jan van der Watt, Cas Vos, Wil Vosloo and Conrad Wethmar need mentioning.

\section{Official collaboration with the Church ${ }^{6}$}

The lecturers of the Faculty collaborated in official commissions and other initiatives of the Church (also together with other Churches in the country), such as the translation of the Bible (1953) and the Bible with Expository Annotations (1958). In this regard Prof. E.P. Groenewald did exceptional work. The following people served on the Hymnal Commission concerning the Psalms: Profs A.C. Barnard (chair), C.J.A. Vos (vice-chair), W.S. Prinsloo and D.J. Human. Profs. C.J.A. Vos (chair), A.C. Barnard, S.J. Joubert and J.G. van der Watt served on the Joint Hymnal Commission. Many also assisted with the Church's viewpoint on important matters such as understanding the Bible and the confession, and homosexuality.

No official viewpoint of the Church has been formulated without the collaboration of lecturers of the Faculty. Specific mention should be made of Human Relations and the South African Scene in the light of the Scripture (Ras, volk en nasie in die lig van die Skrif), later replaced by Church and Community (Kerk en Samelewing), as well as the A-Z Manual on Ministry in the Dutch Reformed Church (Du Toit 2002: 61, 86; Acts General Synod 2007: 232-283).

\section{Board of Curators and Examination Commission The Board of Curators}

The Board of Curators (also called the Curatorium) played an important role over the years. Rev. (later Dr) W. Nicol served as chair from 1934 until 1949, when he was appointed administrator of the Transvaal province. He, however, continued to serve as an ordinary member until his death in 1967. Rev. P.J. Viljoen replaced him as chair until Rev. C.B. Brink took over in November 1951. In November 1963 Rev. A.M. Meiring replaced him, and was in turn replaced by Dr S.J. Eloff in November 1970. Rev. D.P.M. Beukes served as chair from November 1977 until November 1979, followed by Rev. J.E. Potgieter, an alumnus of this Faculty. Since November 1987 Rev. G.J. Erasmus, also an alumnus, served in this capacity (Borchardt 1988:44). Since then the post was held in succession by Rev. Freek Swanepoel, Dr Kobus Gerber and, since November 2007, Dr Danie Dreyer.

Several persons served as secretary: Rev. G.D. Worst (1934 to April 1940), Rev. A.J.V. Burger (1940-1951), Rev. J.M. Benade (1952-1963), Rev. J.E. Potgieter (an alumnus, 1964-1970), Rev. J.C. Crots (also an alumnus, 1970-1979) (Borchardt 1988:45). Ironically two alumni of the University of Stellenbosch then served as secretary: Rev. G.J.C. (Mos) Venter (1979-2000) and Dr P.R. du Toit, since 2001 until the post became a full-time post in 2003.

6. The important roles of ISWEN - IMER (Instituut vir Sendingwetenskaplike Navorsing - Institute for Missiological Research) and SEVTO (Centre for Continuing Theological Training) will not be discussed here as they are discussed in other articles. 
Those that served as secretary were, until the year 2000, also the representative of the DRC on the Council of the University of Pretoria.

\section{The Examination Commission}

This commission has an important role to play and acts as a subcommission of the Board of Curators.

The following people served as chair: Rev. P.S.Z. Coetzee (19441948), P.J. Viljoen (1948-1954), C.B. Brink (1954-1961), J.F. du Toit (1961-1963), G.B. Brink (1963), Drs F.E. O’B. Geldenhuys (1963-1975) and P.J.N. Smal (alumnus, 1976-1985), Rev. G.J. Erasmus (also an alumnus, since 1985). Since then this post was held in succession by Dr Willie van der Merwe, Dr Danie Dreyer and since 2008 Dr P.G.J. du Plessis.

The following people served as secretary: Dr J.H. Eybers (1944-1948), Rev. C.B. Brink (1948), Drs F.E. O’B. Geldenhuys (1948-1963), W.D. Jonker (an alumnus, 1963), D.W. de Villiers (1963-1968), alumni A.B. du Toit (1968-1970) and A.J. Smuts (1970-1971), Rev. F.G.M. du Toit (1971-1974), and Drs F.J. Botha (1974-1975) and C.I. van Heerden (1975-1985) (Borchardt 1988:45). Since then Dr P.R. du Toit has served as secretary of the Examination Commission.

\section{Minister for Theological Training}

The need for a permanent person of the Church at the Faculty existed for many years. In 1972 the congregation Universiteitsoord pleaded for such a public relations post that could also see to secretarial needs. In view of the fact that the congregation wrote a letter to the Synodal Commission of Northern Transvaal regarding more efficient ministry to theological students and their spouses, they were invited to meet the Joint Financial Commission together with the Executive of the Board of Curators.

The congregation Universiteitsoord was willing to enter into an agreement whereby one of the ministers of the congregation would be made available for this purpose. His responsibilities would be to focus on visiting all theological students and those preparing for theological training, including their spouses. He would furthermore fulfil the responsibilities of a minister on an equal level - the balance of his time would be available for the Board of Curators. The congregation would be responsible for $25 \%$ of his remuneration (Borchardt 1988:47).

This proposal, however, never came to fruition. Only at the beginning of the 21st century was the issue raised again, with the shift of the Faculty to a multi-denominational Faculty. Dr P.R. du Toit was appointed by the Board of Curators in 2003 as Minister for Theological Training on a full-time basis while staying ecclesiastically linked to the congregation Universiteitsoord.

\section{Funds}

Immediately after the decision was taken to begin with theological training in Pretoria, the necessary fundraising commenced.

The synod decided to raise $£ 30000$ (R60 000). The interest on this amount would be used to meet the necessary obligation towards the University. A sub-commission of the Theological Faculty Commission with Rev. P.J. Viljoen of Heidelberg as chair was entrusted to raise this amount. In each of the 11 presbyteries someone was appointed to raise more or less $£ 3000$ per presbytery. The minutes of the Theological Faculty Commission reflect a real success story of organisation under the enthusiastic guidance of Rev. P.J. Swart of Greylingstad with a committed team of co-workers and collectors on presbytery level (Borchardt 1988:52).

It is really remarkable that Rev. Piet Swart, who initially opposed the idea of a theological Faculty and even voted against it, was eventually responsible for the greatest part of the fundraising.
The initial goal of $£ 30000$ was surpassed in a short space of time (ed. Van der Watt 1988:16; Borchardt 1988:52).

During the fundraising history of the Faculty various smaller funds were established. One of the biggest investments in theological training has proved to be the De Jager-Steyn Fund. A large amount was received in royalties from the coal on these farms. Other funds that deserve mentioning were the Joubert Fund (named after a donation by Mrs Joubert, the wife of the late Commandant-General Piet Joubert) and the M.S.B. Kritzinger Fund (established through royalties from this person's involvement with Afrikaans dictionaries). Many of the smaller funds were consolidated in the Theological Students Training Fund when the unbundling of the four synods in the Transvaal was resolved in the first few years of this century.

\section{Stressful times for both Faculty and Church}

The closer the ties between the organised Church and the Faculty, the more likely it will be that each reflects the marks and tensions of the other. Theology does not exist in a vacuum.

The establishment of the Faculty coincided with the outbreak of World War II. Following that time, apartheid (the system of separate development) played a major role - especially in the period from 1948 until the Church eventually realised it was a sin in 1986. This whole period was thus also closely linked to the politics of the day and the normal differences regarding this also surfaced. In between there were smaller differences, regarding secret organisations such as the Broederbond and eventually regarding so-called problems with sound doctrine.

\section{Tension regarding apartheid}

Prof. E.P. Groenewald played a crucial role in establishing the theological foundation for the system of separate development of the various race groups (apartheid) in South Africa. This led to a serious difference of opinion between himself and Dr Ben Marais at the Transvaal Synod of 1948. At that time Marais was minister in the congregation Pretoria East. In 1953 he would become a colleague of Groenewald at the Faculty, responsible for the Department of Church History and Church Polity (until 1974) (Maritz 2003:59). Marais was always of the opinion that apartheid could be justified on practical grounds but not on a theological (biblical) basis.

During the years following 1948 there were many stressful periods in the Faculty.

Prof. Marais wrote a book entitled Kleurkrisis in die Weste (which translates as 'The crisis of colour in the West') in 1953, just prior to his assuming responsibility as lecturer at the University of Pretoria. Several people were asked to review the book for various magazines. All of these people were members of the Broederbond: A.B. du Preez and E.P. Groenewald (both of them would be his colleagues at UP in the near future) and T.N. Hanekom of Stellenbosch (Serfontein 1982:99-105).

In May 1955 Prof. Marais was one of 13 academics that signed a petition against the extension of the South African Senate. The South African government implemented this move in order to have a two-thirds majority during a joint session of Parliament and Senate, so that they would be able to pass legislation against having Coloured representatives in Parliament. This action by Marais caused further tension amongst the lecturers (Maritz 2003:52)

There was always a critical solidarity between the lecturers of the DRC and the Church. This also led to several stressful incidents.

In 1960 a few authors from the Afrikaans Churches collaborated to publish a book entitled Vertraagde aksie: 'n Ekumeniese getuienis uit die Afrikaanssprekende kerk ('Delayed action: An ecumenical 
testimony from the Afrikaans-speaking Church'). Prof. Marais had contributed an article called 'Die Kerk in die huidige wêreld' ('The Church in the contemporary world').

At the meeting of the synod of the DRCT in April 1961 not only the resolutions of Cottesloe (regarding race relations) were discussed, but also the book Vertraagde aksie. Marais was abroad at the time. A Church council requested the synod to pass a resolution whereby NG Kerkboekhandel (DRC Booksellers) would be requested to stop selling the book. The synod decided that nothing would be attained with such a decision. However, they decided to request management not to sell any books of a dissident nature.

The synod was also asked by a few Church councils to denounce the viewpoints expressed in Vertraagde aksie. The synod did denounce the statements in Vertraagde aksie that were not in accordance with clear ecclesiastical confessions. Seven Church councils demanded that action be taken against the authors of the book. Since only five authors were Dutch Reformed and they were not all from the Transvaal, the synod resolved that any possible action rested with the appropriate ecclesiastical courts under whose jurisdiction they fell.

Due to requests by Church councils the synod asked ministers, members of Church councils and members of congregations to refrain from irresponsible, confusing and sensational statements and utterances. These remarks could reflect badly on the Church and also cause damage to the work of the Lord. The synod stressed that relevant issues should receive the necessary attention at the appropriate meetings (Borchardt 1988:49).

\section{The Reformation Day Testimony}

On 31 October 1980, eight lecturers of Stellenbosch and Pretoria published a testimony in Die Kerkbode (generally referred to as the Reformation Day Testimony). The lecturers from Pretoria who signed this testimony were A.B. du Toit, J.A. Heyns and C.F.A. Borchardt (Du Toit 2002:147)

In this testimony the lecturers voiced their concern regarding the apparent inability of the institutionalised Church in South Africa to fulfil its God-given calling of reconciliation in a meaningful and trustworthy manner. The testimony pleaded with office bearers and members of congregations to prayerfully strive to abolish loveless and racist inclinations and acts that lead to offensive situations. Furthermore a call was made to work towards visible Church unity with new fervour (Borchardt 1988:49-50).

Following the annual meeting of the Board of Curators in November 1980, a meeting of all the ministers in the Transvaal was held at the Hartebeespoort Dam at the beginning of 1981 (see the article by Van der Merwe and Vos).

Later in 1981 the book Storm-kompas: Opstelle op soek na 'n suiwer koers in die Suid-Afrikaanse konteks van die jare tagtig (which translates as 'Storm Compass: Essays seeking a true course in the South African context of the eighties') was published. The editors were Prof. Nico Smith, Dr F.E. O'B. Geldenhuys and Dr Piet Meiring. In it Prof. J.A. Heyns wrote " $n$ Teologiese Perspektief' ('a theological perspective') on the Church and Rev. Malan Nel gave a commentary on an article by Ilse Treumicht entitled 'Die Uitdaging van sy jongmense' ('The challenge of its youth'). The Board of Curators at their meeting in November 1981 expressed their concern regarding the effect of the publication amongst its members but their concerns were apparently adequately addressed by Prof. Heyns (Borchardt 1988:50).

\section{Tension regarding the Afrikaner Broederbond}

During the course of time there was a certain amount of stress within the Faculty due to the fact that Ben Marais was heavily opposed to secret organisations such as the Afrikaner Broederbond, while some lecturers, such as A.B. du Preez and E.P. Groenewald, were members of this organisation.
In later years there would also be tension between Faculty members who were members of the Broederbond. For example, Prof. Carel Boshoff, who at one stage was leader of the organisation, belonged to the more conservative faction in the organisation, while Johan Heyns belonged to the more liberal faction (Serfontein 1982:190, 202).

\section{Tension regarding the orthodoxy of the doctrine during the eighties}

Theology can never only be the retelling of theological insights from previous generations. That would imply that theology is not alive. The mere reiteration of sterile, concluded theology can never be part of any institution where theology is taught.

Understandably theology should always be taught from a certain perspective. Theologians belong to a certain Church with a specific doctrine - in this case the reformed doctrine.

The risk for misunderstanding within the Faculty has certainly increased as a result of the integrated course, since students do not have the opportunity to develop a scientific approach when they start their theological training.

After completing his studies the young Rev. Heiberg lodged complaints against a large number of lecturers at the Faculty during the years 1989 to 1990 . These complaints were regarding: liberal theology, heterodoxy and being to accommodating towards Roman Catholicism. When Rev. Heiberg was invited to discuss the matter with the Dean and other lecturers he did not oblige. $^{7}$

\section{Student as pawn in the Internet era}

In early 2000 there was an attempt to arouse suspicion against certain lecturers of the DRC. Unfortunately people behind the scenes used a student (albeit willingly) to lead this attempt.

Modern technology, in particular the Internet, was used to create suspicion on a large scale. This was done by placing documents on the web, using chat rooms and using e-mail very effectively. All of this created the impression that the attempt was more extensive than it really was.

To understand the complexities of the situation that developed it is necessary to give a short background. The effect of a multidenominational Faculty as well as the precise curriculum received much attention after 2000. Among others, a successful discussion was held at the end of March 2004 at the congregation South East Pretoria. Lecturers, members of the Board of Curators and the Examination Committee and other ministers were invited. At this meeting there was a serious discussion regarding the Faculty. Subsequent to this meeting, there was also a meeting between the Synodal Commission of Eastern Transvaal (at their request) and the Executive of the Board of Curators (Acts Eastern Transvaal 2005:229).

At the annual meeting of the Board of Curators in November 2004 cognisance was taken of a certain letter by fourth-year students regarding certain lecturers. Following thorough discussion at the meeting a commission was appointed to investigate the whole situation. Drs Andre van Niekerk, James Kirkpatrick and Rev. Elize Klut did their utmost to visit every class group and to have extensive discussions with them so as to determine what the true nature of the problem was and if it had any substance. They regarded themselves as a commission that would 'listen'. They reported their findings in March 2005. A wide range of subjects were reported on; among others the following:

- The Board of Curators was urged to pay urgent attention to the induction programme of first-year students.

- The Board of Curators declared that, although students were generally positive regarding their lecturers, they

7.See Van der Merwe and Vos for a detailed description of this case. 
had an obligation towards those lecturers that are always disrespected by a group of students.

- It was recommended that lecturers be asked to be sensitive to the impact on students when they are introduced to theology as a science. Lecturers also have the responsibility to help students to align their theological viewpoints with their faith.

- It was decided that there was not enough opportunity for building good relations between lecturers and students, and that it should be the responsibility of the Board of Curators, in collaboration with lecturers. The Board of Curators was also of the opinion that there should be an ongoing discussion with students regarding the theme of 'the authority of Scripture' and other relevant theological issues, and that lecturers had a responsibility in this regard.

All of the above issues were thoroughly discussed on 21 April during a meeting between the commission and lecturers. Except for this discussion, the complete report was distributed to everyone in the Faculty, including the students (Acts Eastern Transvaal 2005:229-230).

Over the short term certain changes were made. This was followed by, among others, certain extra modules in Liturgy and Homiletics.

\section{A student acts as spokesperson for the onslaught on the Faculty}

Mr Ferdie Mulder, a student in his early thirties, was apparently of the opinion that he should question the religious convictions of his lecturers, starting in his first year (2001). After only two weeks at the Faculty he raised certain objections regarding theological liberalism. He furthermore kept record of his conversations with lecturers and ministers and his interpretation of those conversations.

Following the General Synod of 2004, Mr Mulder issued a general statement in which objections were voiced regarding the resolutions of the General Synod concerning homosexuality. It was later established that this statement also contained names of fellow students that he added in a irresponsible way (without their permission) so as to imply that they were also complainants. In any case, because of this statement the newspaper Beeld interviewed him and four fellow students. The article, which was published with an accompanying photo in Beeld in 2004, made public the fact that four UP students were discontented with the resolutions of the General Synod. They even stated that if the Church should allow homosexuality in the Church, they would resign their membership (Beeld 7 December 2004).

At the beginning of his fourth year Mr Mulder wrote a letter to the Board of Curators concerning certain matters, with the request that it should be dealt with anonymously. The Board of Curators judged that there was not enough substance to his concerns to necessitate further investigation. At that time the 'listening' commission was also addressing all the relevant issues.

The onslaught against the Faculty took an ominous turn, however, when an article questioning the theological training at the University of Pretoria was published in the Rapport of 22 May 2005. This article was the result of a long document that Dr Jan Grey gave to a journalist at Rapport. A further article was published in the 2 June 2005 edition of Rapport (Rapport 22 May 2005; 2 June 2005).

On Sunday evening, 29 May 2005, a recording was made for the RSG radio programme Oop Gesprek 'Open Conversation'. The recording was made in the Church building of the congregation Kameeldrif. This was broadcast the following Sunday evening, 5 June 2005.

During the week preceding this radio broadcast Mr Mulder, via e-mail and on a large scale, invited ministers to listen to the broadcast. He stated that 'there would be talk of a possible crisis in theological training. The speakers are Prof. Julian Müller, Dr Kobus Gerber, Rev. George Nel and Dr Jan Grey'. The Board of Curators were given correspondence in which Mr Mulder declared that 'the radio programme describes the liberal notion that becomes more dominant in theological training. In this context I [Ferdie Mulder] would classify liberal as those that deny the virgin birth and the physical resurrection of Jesus'.

The unsubstantiated accusations made in the Rapport articles and in the radio programme compelled the three Boards of Curators to issue a joint statement on 8 June 2005:

The Executives of the Boards of Curators of the Dutch Reformed Church (Stellenbosch, Pretoria, Bloemfontein) are disappointed with the way in which lecturers as well as the Boards of Curators came under suspicion by ministers of the Dutch Reformed Church (specifically the articles in Rapport of May 22 and June 5 and the Oop Gesprek ('Open Conversation') on June 5). Lecturers and the Boards of Curators were unfairly accused by unsubstantiated generalisations of theological liberalism and even erroneous doctrine.

This way of labelling is not conducive to healthy theological discussion regarding important issues of faith. If there should be well founded doubt regarding the theological soundness of any lecturer or member of the Board of Curators any member or minister of the Church can lodge a founded complaint with the appropriate ecclesiastical body. It will then be properly investigated. Accusations of a general nature in the public press only cause confusion and discord. Believers do not treat each other in this manner. Unfounded accusations without any brotherly discussions or formal complaints being lodged are an un-biblical way of doing things.

The different Boards of Curators declare their trust in and their appreciation for all the theological lecturers under their jurisdiction. These persons make a great contribution towards the effective training of ministers. As believers in the service of the resurrected Christ they contribute as academics of excellence a positive influence towards the theological discussion of our day.

This document was signed by the chairpersons and scribes of the three Boards of Curators (Stellenbosch: C.W. Burger and M.D.J. Smith; Pretoria: J.J. Gerber and P.R. du Toit; Bloemfontein: G.P.V. le Roux and R.R. Botha).

\section{A so-called Status Confessionis surfaces}

The DRC held a general meeting of all their ministers (legitimised persons) from 21 to 23 June 2005 in Bloemfontein. Mr Mulder was allowed by grace to attend the gathering. During two group discussions he made many unsubstantiated accusations regarding theological lecturers. Also at this gathering he distributed a document entitled 'Status Confessionis regarding Jesus' resurrection' to a few ministers (Die Volksblad 22 June 2005; Kerkbode 8 July 2005).

This document stated the following:

We believe that Jesus Christ was raised historical-literally and physically from the dead .... We differ from viewpoints declaring that the resurrection of Jesus was not historical-literally and physically.

Such theories state among others that Jesus' resurrection was "figuratively", "metaphorical", "not literally", "mythological", "symbolic", is a pre-modern "world view" declaration, and that the resurrection does not entail 'historical importance.'

These words were ascribed to Julian Müller, Dirk Human, Ben du Toit, Jurie le Roux and Louis Jonker. The document ended with the names of 46 students from the University of Pretoria.

At the gathering in Bloemfontein $\mathrm{Mr}$ Mulder made an arrangement with a journalist at Rapport that an article on the Status Confessionis would be published in the next issue of the paper. A photo session with a Rapport photographer was 
arranged at the residence of the Presbyterian students in Pretoria. The intention was apparently to publish an article on the front page that Sunday. However, due to certain appeals, this onesided and unsubstantiated report was not published.

This Status Confessionis was basically a declaration of faith. Although this one was poorly worded, there is nothing wrong with such a declaration. The declaration was made, however, in the name of 46 students of the University of Pretoria. The second part of the declaration states that five theologians of the DRC did not agree with this basic article of faith. Three of the five theologians are lecturers at the theological Faculty at the University of Pretoria. This declaration of the students was published in both Die Burger and Beeld (Die Burger 25 June 2005; Beeld 25 June 2005).

The Executive of the Board of Curators at UP took an extraordinary step by publishing another document on 11 July 2005 (Beeld 31 July 2005). This document contained the following declarations (all press releases in Afrikaans - here referred to in translated form):

- the one by the three Boards of Curators referred to above (dated 8 June 2005),

- one by the dean (dated 25 June 2005),

- one by the three lecturers (dated 1 July 2005), as well as

- another by the Board of Curators.

In the last declaration by the Board of Curators a few extraordinary matters were addressed such as the commitment to give clarity, be transparant and even to lenghten the normal annual meeting. Everything regarding the allegations was brought to the attention of congregations, ministers and students within the synodal boundaries of Western, Northern, Southern and Eastern Transvaal. Ministers, members and students were requested to give their comments.

The Executive stated that they were convinced that by issuing these declarations all the questions that arose would be answered satisfactorily. In order to be transparent the Executive declared that they were willing to comply with the following procedures in order to reach a satisfactory conclusion:

- Members, ministers and students were requested to read all the declarations very carefully.

- If any questions remained or there was not clarity regarding these issues it could be brought to the attention of the Minister for Theological Training in Pretoria before 10 Augustus 2005 (all relevant addresses and contact details were supplied). The request was to be specific regarding the relevant issue and to supply the Executive of the Board of Curators with all the relevant information regarding the allegation.

- On 10 August 2005 the Executive of the Board of Curators would appoint a committee to report their findings regarding the comments that are received to the Executive before the end of September 2005.

- If necessary, specific questions would be directed to each lecturer. They would be requested to answer in writing before the end of October 2005.

- The committee's report would be discussed in detail at the meeting of the full Board of Curators at the end of 2005. This meeting would be extended by a whole day in order for the Board of Curators to have separate meetings with each lecturer individually and, if necessary, get clarification from everyone concerned. Thus any future enquiry could be answered clearly and with certainty.

- Following the meeting of the full Board of Curators a complete declaration concerning the relevant issues would be issued. If certain steps would need to be followed it would be stated in a transparent way.

Attached to this invitation there were the two press releases by the Faculty: one by the dean and one by the three lecturers.

The press release by the dean stated the following:

During the past weeks there was much discussion in the ecclesiastical as well as the secular press concerning the authority of Scripture and the person and labour of Christ. Those issues touch the deepest religious convictions of Christians.

The Faculty of Theology at the University of Pretoria again reconfirms its solidarity with the Church and desires to confess with and as part of the Church the belief in the crucified and resurrected Christ.

This Faculty is a multi-denominational theological Faculty. The Faculty houses Reformed Churches which fully subscribe to the Reformed theology and lectures it.

Commentary is given on the following issues:

\section{The task of theology}

Theology has an academic task that needs to be taken into serious consideration. This entails, inter alia, that there should be scientific engagement with theological discussions. In these discussions al theological viewpoints should constantly be tested with the Biblical witness and the ecclesiastical tradition. All theological viewpoints always carry with them the marks of preliminary perspectives.

Except for their academic task, theologians of the Faculty also have a responsibility towards the Church and the society as a whole. This always demands a constructive involvement as well as a critical voice.

\section{The authority of Scripture}

The Bible is the Word of God, the source from which the community of believers think, believe and work. The Bible should be understood within its own context and framework. By listening to what God told his people in the past, the Church can discover what God's message entails at present.

\section{Jesus Christ, the Lord}

We believe that Jesus Christ is the Son of God. He was born from the Virgin Mary and on account of that we believe that He truly was God and human.

We also believe that Jesus Christ was resurrected from the dead on the third day. This is the source of the belief of Christians that He overcame the might of the death and conquered all chaos. This faith is a mystery. Therefore believers live in awe before God.

Prof. C.J.A. Vos

Dean: Faculty of Theology, University of Pretoria

(Beeld 25 June 2005)

Profs Dirk Human, Jurie le Roux and Julian Müller, lecturers at the Faculty of Theology at the University of Pretoria, in their press release "concerning the "false doctrine letter" of Mr Ferdie Mulder and others', stated among other things that they, 'together with other colleagues were labelled wrongly and treated unfairly by the instigator of this, Mr Ferdie Mulder, and those that support him' (part of the widely distributed Request for Commentary by the Curatorium, dated 11 July 2005) .

They went on to say that this so-called Status Confessionis created false perceptions regarding their personal viewpoints concerning the resurrection of Jesus and resulted in the public tarnishing of their names. In an unfair manner these false perceptions caused them personal and public sorrow. Furthermore this had a negative effect on any public theological debate. They stated that they found this way of doing things by so-called zealots for the Christian truth totally unacceptable because:

nowhere did Mr Mulder or any of the signatories meet with us for a 'brotherly discussion' regarding any issues - that would have been the appropriate way;

no one lodged a complaint regarding false doctrine or inappropriate conduct at either the Board of Curators or the authorities at the University;

in the Status Confessionis the content and spirit of our academic work is being misjudged and distorted, with the consequence that it sounds as if we proclaim a false doctrine regarding the resurrection - this way of doing we regard as unchristianly and without love; 
it also seems that Mr Mulder misled many students into signing this Status Confessionis.

(Die Burger 2 July 200502.07.05; Beeld 5 July 2005)

They concurred with the spirit and content of the press release by the dean and reiterated that on Sundays they confess the resurrection of Jesus Christ with the Church as is expressed in the Apostolic Creed.

It was therefore quite clear that the Board of Curators had to take action. Two issues had to be dealt with: firstly, the unethical conduct by a theological student and secondly, the endeavour to restore public trust regarding theological training (after receiving comments in response to the invitation extended).

\section{Action regarding Mr Mulder}

The dubious way in which the names were added to the Status Confessionis resulted in the Board of Curators taking disciplinary action against $\mathrm{Mr}$ Mulder.

The Status Confessionis contained 46 names of students of the Faculty of Theology - some of them signed, most of them only added. However, upon further investigation all the students, with the exception of Mr Mulder (and later on one of his close friends), distanced themselves from the document (Die Burger 27 June 2005; Beeld 27 June 2005; 30 June 2005). This caused the Executive of the Board of Curators to bring charges of ill conduct against $\mathrm{Mr}$ Mulder regarding alleged untruthfulness. The charges concerned the way of conduct (the ethics involved) and not the content of the allegations (the doctrinal issues). These allegations were to be investigated ecclesiastically.

The students and lecturers of the Uniting Presbyterian Church were appalled by their students (not being conversant in Afrikaans) being misled. They, among others, prohibited $\mathrm{Mr}$ Mulder from ever visiting their residence again.

The Board of Curators intended to conclude the matter as soon as possible; however, that was not to be.

The Executive of the Board of Curators wished to investigate the conduct of Mr Mulder in a reasonable way as described by the appropriate ecclesiastical bylaws pertaining to such a matter. $\mathrm{Mr}$ Mulder attended the hearing by the Executive of the Board of Curators on 11 August represented by senior counsel. At this meeting the advocate demanded that Mr Mulder should have legal representation (Beeld 14 August 2005). The Executive eventually complied with this request. The next meetings were scheduled for 14 and 16 September. This, however, did not suit Mr Mulder's legal counsel, and eventually the dates were set for 4 and 5 October. During this meeting Mr Mulder's legal counsel argued that there was a perception of prejudice by the Executive of the Board of Curators against Mr Mulder. In reaction the Executive made the following statement: '[T]he Executive of the Board of Curators do not regard themselves as prejudiced. However in view of the perceived perceptions by Mr Mulder and with the intention to speedily resolve the issue, the Executive decided to recuse itself and to request the Board of Curators to appoint a committee to attend to this case as soon as possible'.

The committee that would handle this case on behalf of the Board of Curators consisted of Rev. J.H. Windell (chair), Actuary of the Southern Transvaal Synod, Rev. H.J.G. Fourie (of Western Transvaal) and Rev. J.J. Louw (Actuary of Western Transvaal). Adv. Marius Helberg SC and Mr Henning Viljoen represented Mr Mulder. Adv. J.I. du Toit and Mr Hans Oosthuizen of Couzyn, Hertzog and Horak represented the Board of Curators. Adv. J.W. Louw SC was asked by the Board of Curators to act as a legal assessor of the proceedings.

Eventually a press release regarding the disciplinary hearing of Mr FS Mulder was issued on 17 March 2006 by the Board of Curators:
The committee appointed by the Board of Curators regarding the allegations of dishonesty by Mr F.S. Mulder had held meetings on 22 and 23 February and 6 and 14 March 2006 and had made their recommendations and punishment public on 17 March 2006

The committee found $\mathrm{Mr}$ Mulder guilty on several charges of misconduct. Among others it concerned the composition, signing, altering and distribution of the so-called Status Confessionis which was allegedly signed by 46 students. The punishment imposed on Mr Mulder was the following: 'The Committee hereby suspends Mr Mulder's admission to the ministry until he can convince the Board of Curators of the Dutch Reformed Church of Transvaal of his repentance regarding this misconduct'.

The Executive of the Board of Curators regret the fact that there was such conduct whereby many innocent students became involved. The detrimental results of this document in the Dutch Reformed Church and the theological faculties where students of the DRC receive their training are also deeply regretted.

(www.teo.co.za/wmview.php?ArtID=302)

The one result of this conviction was that Mr Mulder could not complete his requirements for the congregational year. No pardon was asked or given until the end of 2008.

It was not an easy decision for the Board of Curators to take disciplinary action against Mr Mulder. The Board of Curators had all along endeavoured to abide by an ecclesiastical way of doing things. At the request of Mr Mulder and his legal council it was agreed to handle the issue in a legal manner. Mr Mulder was thus eventually convicted on several counts of misconduct in this disciplinary hearing (Beeld 29 March 2006; Kerkbode 14 April 2005).

The University of Pretoria had its own disciplinary hearing regarding $\mathrm{Mr}$ Mulder. The University decided to take this action because the name of the University was involved and the integrity of the lecturers was questioned. The trust between lecturers and other students was also impacted on. The investigation was led by a former Supreme Court judge, Buddy Swart. It was determined that Mr Mulder falsely accused the lecturers of dishonesty or probable dishonesty. Consequently he was disallowed to register for any other theological degree at the University of Pretoria (Beeld 22 December 2006; Kerkbode 26 January 2007).

\section{Action regarding comments that were received}

The Board of Curators extended the well-intended invitation to respond to matters regarding theological training on 11 July 2005. It was sent to the four synodal offices of the synods in the Transvaal. Every office distributed this in its own way to the different congregations.

This was all done in an effort by the Board of Curators to handle the matter transparently.

However, this conduct did not satisfy Mr Mulder. He distributed five academic articles (written by three lecturers and two members of the Board of Curators) via e-mail to professors, doctors, ministers, Church councils and members. The fact that these articles were accompanied by a letter written by 'a colleague' asking them to respond to the office of the Board of Curators created the impression that this was sent by the Board of Curators.

Mr Mulder not only sent these articles to congregations within the synodal territory of the Transvaal, but to e-mail addresses everywhere. He did this from the personal computer of 'dgrey' (the son of his friend Jan Grey). D. Grey later made the following comment: 'A theological student used my computer to send hundreds of e-mails because my computer had a 1 Gig memory and he was in haste. I myself do not know what he has written. It was a favour done with my consent. I have nothing to do with it and I only know that it concerns him and the Church and some quarrels' (e-mail D. Grey to J.J. Gerber: 26 August 2005). 
It would have been interesting to know how many responses would have been received if Mr Mulder did not create this false impression using the name of the Board of Curators.

After receiving the responses (from positive to negative around 30 letters) it appeared that there were only two pertinent complaints against the doctrine of the three lecturers (from the Church council of Middelburg West and Rev. Etienne Maritz). The Board of Curators handled these accusations without any comments to the presbyteries in whose area the lecturers were members of a congregation (the presbytery of Pretoria Faerie Glen in the case of Prof. D. Human and the presbytery of Pretoria East in the case of Profs Jurie le Roux and Julian Müller)

The Board of Curators expected the responses to be sent directly to the Board. In at least two instances people saw an opportunity to not only respond to the Board but to send it by e-mail to hundreds of ministers whose e-mail addresses they had.

Mr Ferdie Mulder distributed a 37-page document that contained his response to the invitation by the Curatorium electronically very wide - even overseas. Hard copies were also widely distributed and the document was posted on at least one website.

Dr Jan Grey also distributed a document (his response to the invitation by the Curatorium) of 49 pages also electronically locally and abroad (According to unsubstantiated information received it was sent to 2200 e-mail addresses).

Without focussing on the content regarding lecturers and ministers of the Dutch Reformed Church, it should be mentioned that the responses distributed by these two also involved other denominations and instances. The way in which conversations were reported in $\mathrm{Mr}$ Mulder's document caused tension. Without consent he made voice recordings of conversations and used transcriptions of these in his document. Three prominent people from the NRCA reacted by letter: Prof. Johan Buitendag, Dr Ernest van Eck and Dr Daan van Wyk (chairperson of their Board of Curators) (Beeld 06 September 2005). This tension also involved the Uniting Presbyterian Church and the relationship with the University of Pretoria.

Mr Mulder's document caused much harm. For example, an article in Vrye Afrikaan (19 August 2005), the magazine of the FAK, talks of the 'rebellion' by 46 students of the University of Pretoria. In spite of all this Mr Mulder lodged a complaint of negligence against the whole Board of Curators on 30 September 2005. This complaint he addressed to the four synods in the Transvaal.

A great deal of confusion was created in the Church with regard to theological training. Some complaints that still needed to be investigated were posed as the truth. In the process it discredited lecturers. Over and above the tension it caused among students, people were not accustomed to the fact that uncontrollable accusations were distributed on such a scale over the Internet.

\section{The process regarding the three lecturers and sound doctrine}

The Board of Curators extended the invitation for responses in 2005. In a few cases complaints regarding unsound doctrine were being made. This left the Board of Curators with no other option than to bring it to the attention of the presbyteries to investigate. This proved to be the best way of handling the situation. Every possibility of prejudice was thus removed. In this way no accusations could be made that the Board of Curators did not attend to these serious complaints.

The presbyteries properly and thoroughly investigated the matters, observing the resolutions taken by the General Synod regarding the handling of Scripture. When all the judgements were passed a press release was issued on 20 September 2006.
It was sent to the media and also placed on the website of the General Synod. It read as follows:

\section{Points of departure}

The Board of Curators of the DRCT gladly and with confidence declares that theological training should be conducted in such a manner that ministers be prepared in such a way as to serve the congregations and the wide variety of members effectively.

The training at the University of Pretoria is as always true to Scripture and Reformed according to the recognised Reformed opinion regarding the Scriptures, the creeds and, to the extent it concerns the students of the DRC, in accordance with the resolutions of the General Synod of the DRC. Furthermore it wants to take into consideration, in a contemporary manner, the demands being placed on the theology of our time.

This press release is being issued because the Board of Curators gave the undertaking earlier to keep the denomination informed.

\section{Situation regarding the lecturers}

The Board of Curators is consequently much obliged that two separate presbyteries (that of Pretoria East and the one of Pretoria Faerie Glen) who handled the cases of the three lecturers that were accused of unsound doctrine, were acquitted. The involved lecturers' cases were handled by the Presbytery of Pretoria East, in the case of professors Jurie le Roux and Julian Müller, and the Presbytery of Pretoria Faerie Glen, in the case of Prof. Dirk Human. The Board of Curators is grateful that these verdicts reiterate the confidence that the Board of Curators had in all the lecturers all along.

The following excerpt from the verdict of the Presbytery of Pretoria East is of importance for the whole denomination:

It was very clear from the beginning that the accusation being lodged and Prof. Müller's defence implied a certain tension. This being: on the one side the "tradition" - which one complainant (Rev. Maritz) called "old, sure truths" - and critical-theological (faith) justification.

It was clear that the complainants represented the "tradition" while Prof. Müller's defence should be seen as "critical-theological justification". It thus is also clear that this tension is a broad-based reality in the life of the Church and in the hearts of believers. The commission had to take cognisance of this.

The commission, in hearing and studying the complaints and the defence, continuously took cognisance of the resolutions of the General Synods $(1998,2000,2002)$ concerning the authority of the Scriptures and the creeds as historical documents. The commission was of the opinion that the resolutions of the General Synod regarding these two issues were the recognised criterion to determine the merits of the complaint against the accused and to come to a conclusion.

Even a cursory "reading" of the resolutions of the General Synod, to which attention were [sic] drawn earlier, shows that (the) synod regarded it feasible to go the way of candid critical debate regarding matters of faith in our time.

Judging on this the commission unanimously came to the conclusion that Prof. Müller - regarding that which he was accused of-acted within the spirit and letter of the relevant synodal resolutions.

The commission is of the opinion that Prof. Müller in his task as theologian can rely on the resolutions of the General Synod. It is evident that the synod in its resolutions regarding the authority of the Scriptures and the creeds tried to bridge the gap between "tradition" and "critical faith justification". The commission concluded that this is precisely what Prof. Müller tries to achieve. Prof. Müller sees his own theological position, which he describes

as "post-fundamental", as one whereby both fundamentalism and relativism can be sidestepped.

It is also clear to the commission that the complaint against Prof. Müller depends largely on a deficiency in understanding the 
conventions whereby theological debate is being conducted and the recognised principles of rhetoric. ${ }^{\prime 8}$

\section{Situation regarding student Mulder}

It was no easy decision for the Board of Curators to take disciplinary action against student Mulder. The Board of Curators had all along endeavoured to abide by an ecclesiastical way of doing. On the request of the student and his legal council it was agreed to handle the issue in a legal manner. The student was thus eventually convicted on several accounts of misconduct in this disciplinary hearing regarding his part in the composition and distribution of the Status Confessionis document. He was given the opportunity to ask for pardon. Up to now there was no word of pardon or regret regarding the situation.

4. Public interest in theological training at the University of Pretoria

Although everyone can ask legitimate questions regarding the soundness of doctrine of theological lecturers at the University of Pretoria, it is a pity that this matter could not be conducted in a brotherly manner and that it was taken to the public media.

\section{Grateful for response}

The Board of Curators was very grateful for people's response. Those responses were evaluated by an appointed commission. Certain deficiencies in our process (mostly concerning Church polity) were pointed out and will receive further attention.

\section{Other matters that need attention}

The Board of Curators want to serve the Church in the best way possible. The Board of Curators has a responsibility towards the students, the lecturers and the Faculty and has endeavoured to serve the interests of all the parties on behalf of the Church as best as possible.

There are most certainly matters that need attention. This is especially true of the existing curriculum as well as the proposed new structure for theological training.

\section{Apology}

The Board of Curators wants to express its deep regret in as far as its conduct and that of its students and the issues concerning the lecturers did not serve the kingdom of God as well as it should have. To the extent that the matters caused a public embarrassment the Board of Curators as the responsible commission truthfully beg your pardon.

It really is a shame that our brothers from the NRCA and the students of the Uniting Presbyterian Church were implicated in the matter. The Executive of the Board of Curators want to express our deep regret towards them. This especially applies to Profs Johan Buitendag, Ernest van Eck and Dr Daan van Wyk Jr (Chairperson of the NRCA's Board of Curators).

\section{Confidently ahead}

The Executive of the Board of Curators wants to continue with the responsibility of serving the kingdom of God as well as the interests of the Church as well as possible in these trying times. This should be done by a well-founded scientific and Scripturally bound theological training. To achieve this we need the support and prayers of the Church.

This was issued on behalf of the Executive of the Board of Curators by Drs Kobus Gerber (Chairperson of the Board of Curators) and Flip du Toit (Minister for Theological Training).

(Kerkbode 13 October 2006:6)

\section{Further onslaught by means of a DVD}

The Faculty (and indirectly the DRC Board of Curators) suffered from all the negative responses on the Internet by way of e-mails

8.Prof. Julian Müller wrote a book regarding this experience. It is entitled Opstanding ('Resurrection') and in it he reflects on the influence of the resurrection. and certain websites. A new kind of challenge was also posed through a new medium: an alarmist DVD was distributed and viewed on a large scale. It was even given to DRC members by members of other denominations. This DVD would have been published prior to the General Synod of 2007; however, there were delays in its publication.

At a later stage it was determined that Mr Sarel van der Merwe, a member of a DRC congregation in Krugersdorp, was the person responsible for this DVD. He intended to further the cause of Ferdie Mulder - without responsibly dealing with the facts or even contacting the people he referred to. The DVD was entitled "Nuwe" strominge in die teologie. Word die hart van die evangelie uitgeruk?' (which translates as " $\mathrm{New}$ " currents in theology. Is the heart of the gospel being torn out?'). It was produced by WTL productions.

This DVD had the advantage of visuals. The problem was that the images were arranged in such a way that a wide variety of theologians were indiscriminately bundled together to create a certain impression. In a very irresponsible way pronunciations of, among others, Desmond Tutu, Marcus Borg and Croisan were neatly tied together. This was combined with the pronunciations of the so-called New Reformers in South Africa, namely Sakkie Spangenberg, Hansie Wolmarans, Piet Müller and Pieter Craffert.

Because some lecturers participated in some of these discussions, the DVD created the impression that these lecturers were part of the New Reformation. The intention of the DVD was to scare viewers. There was even a warning in the introduction to the DVD that sensitive viewers might be offended! According to the narrator, the aim of the DVD was to promote scientific research. Ironically, the way in which the facts are structured was not scientific at all. It was deliberately constructed to scare viewers.

A wide variety of philosophical and theological ideas was thrown together. The Jesus Seminar, the New Reformation, Gnosticism, New Age and the Theosophical Society were all linked in an irresponsible manner. The same applies to concepts such as deception, myth, symbolism and metaphor. All these matters were presented as one basket of thoughts, without any distinction. The impression was created that all of this was taught at the theological Faculty at the University of Pretoria (Agenda Eastern Transvaal 2007:156).

The entire production creates the impression of a bush trial (conveniently using all the research of Mr Mulder).

Prof. Dirk Human correctly asks:

Why did the producer(s) deliberately collect visual images of public theological debates over a long period of time without even intending to talk to the lecturers of the University of Pretoria? According to the introduction to the DVD they want to promote theological debate. The way in which the producer(s) of the DVD handle(s) texts and people underscores how they use the Bible and the viewpoints of other people: irresponsibly, selectively, onesidedly and with a lack of insight in their own presuppositions.

(www.teo.co.za/wmview.php?ArtID=576)

Jurie le Roux declared:

The unknown person ... that produced the DVD ... took our own genuine words, took them out of their original context, and combined them with those of others and in this way they acquired a totally different meaning.

(www.teo.co.za/wmview.php?ArtID=577)

The Reformed theologian, Andries van Aarde, was also targeted. This compelled him to write the following:

Because ... (I) am directly and constantly being named, I think it is necessary to point to the fact that faulty information regarding my views is reported in this DVD. This information can be interpreted as malicious. 
I attach copies from some of my publications and Christology lectures that I gave in the Department of New Testament Studies. My viewpoint regarding the birth of Jesus Christ is clear.

On scientific-exegetical and histiographic grounds I believe that the insinuations of 'non-Jesus followers' during the earliest century of the Christian era that the mother of Jesus was a 'prostitute' and that she gave birth to Jesus due to being raped by a Roman soldier cannot be determined. The DVD states precisely the opposite.

Please take note of my disappointment regarding this unevangelical reference to my theology.

(www.teo.co.za/wmview.php?ArtID=578; Kerkbode 24

August 2007:3)

Julian Müller wrote the following:

The line of argument in the DVD is as follows: The false doctrine originated internationally with the Jesus Seminar and from there reached South Africa posing as the New Reformation. The argument then goes that I (and others), without me acknowledging it, am part of the New Reformation and thus, in an undercover way, hold the same views and propagate it. Regarding this, two remarks: This line of argumentation is quasi scientific and very dangerous. It entails the simple and easy linking of people and instances with each other in spite of the fact that they themselves view it otherwise and express themselves otherwise.

Imyself have iterated my viewpoint regarding the New Reformation time and again.

The tracks on the DVD are presented out of context in order to achieve the goal of the producers. The context in which a certain address is given is not explained and an explanation of the circumstances is lacking. In this manner tracks, which are all real recordings, are linked together to reach a certain conclusion. However, there is no intention to explain the real meaning of what is said. If this same method would be used to describe Jesus' creeds and labour, he would easily be portrayed as a glutton, wine boozer, one desecrating the Sabbath, a betrayer of family values (to name only some possibilities)....

I conclude that the DVD is a malicious attempt to send false perceptions regarding me and other colleagues into this world. One can only hope that intelligent viewers will discern it as such.

(www.teo.co.za/wmview.php?ArtID=575)

The Executive of the Board of Curators also took cognisance of this DVD and stated the following in a press release on 15 August 2007:

There is no indication who the producer(s) of the DVD were and in the composition of the DVD there are negative and uncontrolled accusations. Lecturers of the Faculty of Theology are framed without even talking to them. The Board of Curators reject the way in which the producer(s) of the DVD use the words of the lecturers in an unfair manner and out of context to reach their own preconceived goal. Such a precarious hermeneutics gives the impression of a purposeful insinuation against the lecturers. Therefore the Executive wish to draw attention to the following facts in order to give some perspective to the conduct of the lecturers:

Prof. Julian Müller does not regard himself a New Reformer. When he therefore preached at a Reformation day service in the congregation Pierre van Ryneveld (in 2000), and took part in a discussion (after being invited) in the congregation Skuilkrans to elaborate on certain issues, and delivered an address on the New Reformation at the Centurion Theatre on invitation by a Commission of the Eastern Transvaal Synod and at the opening of the Theological Day in 2003 at the request of the Board of Curators, his conclusions should have been understood within the context of the particular discussion. His goal was to further critical debate with the New Reformation. When Prof. Müller encouraged people to read the book by Walter Wink it in no way implied that he agrees with everything that Wink writes. In doing so he is of the opinion that Wink can contribute to a theological understanding of the problems.
When Prof. Jurie le Roux participated in a debate at Unisa in 2002 where he stated that he did not support the statement by the lecturers in 2002, he did not imply that he was against the content of the declaration. He was against the fact of a declaration. He doubted the value of such a way of debating between Christians.

When Prof. Piet Geyser thanked a representative of the Jesus Seminar in a friendly manner the DVD creates the impression that he agreed with everything the person said. This is a misrepresentation of the situation.

These are only a few examples to show that all those that want to further the cause of theological training should work together honestly as brothers and sisters in Christ. In this manner the issue of the kingdom of God is served. In order to further the cause of justice the question of false doctrine was referred by the Board of Curators to the designated presbyteries. They acquitted the lecturers.

Therefore the Board of Curators wish to invite everyone interested to dialogue together during the Spring Conference on the evening of 18 September at 19:00 in the Church of the congregation Universiteitsoord.

(www.teo.co.za/wmview.php?ArtID=579; Kerkbode 14 September 2007; 12 October 2007:5)

\section{The Evangelical Initiative established}

Prof. J.W. Hofmeyr, Head of the Department of Church History and Church Polity, retired at the end of June 2007 at the age of 60. Although it was of his own accord, he later on expressed the view that there were other reasons for his retirement. ('By' in Beeld 6 Sept 2008; Kerkbode 08.06.2007:3) He was instrumental in organising an 'informal discussion' on 20 July 2007 in Pretoria. This meeting gave birth to the Evangelical Initiative (Evangeliese Inisiatief, EI). Dr Johan van Schalkwyk was elected chairperson, Dr Louis Louw vice-chairperson, Dr Jorrie Potgieter secretary and Prof. J.W. Hofmeyr treasurer. The additional members were Dr Louw Alberts, Mr G. Beukes, Mr C.H. Johnsen, Prof. A. Konig, Dr D.J. Malan, Rev. T. Oosthuyzen, Rev. S.J. Scheepers and Rev. D.E. van der Spuy (Kerkbode, 27.07.07:3). They played the "Nuwe strominge' DVD at their meetings in order to support their viewpoint (Kerkbode, 24.08.07:3).

In August 2007 the Dutch Reformed Council of Lecturers of the Faculty of Theology at the University of Pretoria released the following statement regarding the EI:

The Council of Lecturers of the Dutch Reformed Church at the University of Pretoria wants to support any action that wishes to serve and expand the Biblical gospel. The reasons for the establishment of the movement Evangelical Initiative was, however, born out of anxiety. This strange Initiative had, during the previous days in the press and over the radio, in contrast to their written documents, aroused suspicion against several theologians and other Church leaders. In an unreasonable way strange theologies were ascribed to them. The lecturers are in favour of open discussion regarding theological issues that concern theology and the Church. Therefore we invited the Steering Committee of the Initiative to enter into discussion with us on 13 August 2007.

We believe that the theology which we adhere to must show the difference in the Biblical texts, the Church history and our society. It is therefore important for us to equip students with diversity to advance while at the same time adhering to the tradition of our belief system.

We accept the authority of the Bible. The living God talks to people through people. He persuades people by way of his Word to believe and to live a life of faith. Faith means, among other things, to trust God with all our heart and life, to live in honesty before Him and each other. We believe in the triune God. God is the Creator, Saviour and one that fulfils everything in everyone. Jesus Christ became human, died for our sin, and has risen from the death.

This is our heartbeat!

(Kerkbode 10.08.07:3) 
The invitation was supported by the Executive of the Board of Curators with the following press release in August 2007:

The Executive of the Board of Curators at its meeting of 8 August 2007 took notice of the action by the Evangelical Initiative. Having taken notice of certain representatives of the Evangelical Initiative in the media it appears that negative and unsubstantiated accusations are made against the Board of Curators and the Faculty of Theology at the University of Pretoria - without having discussed anything at all.

The Executive of the Board of Curators welcomes any discussion regarding theological training if it is transparent and done on [sic] a responsible and brotherly way (Matt 18:15-20). Therefore the Executive also invited the Steering Committee of the Evangelical Initiative for discussions. They indicated that they will participate when they are ready. Notwithstanding this the Executive of the Board of Curators appointed two of its members to discuss matters with one of the leaders in the Evangelical Initiative.

The EI did not accept the invitation. They preferred to firstly talk to the General Synodal Moderamen of the General Synod. Following this meeting they concentrated all their efforts on their public meeting on 13 October 2007 at the Moreleta congregation. This meeting unfortunately did not meet their expectations 1500 attendees instead of the expected 7000 (Kerkbode 12.10.07:1, 26.10.07:3).

Regrettably not one word was spoken to any lecturer up until October 2008 - the date this article was written. A meeting between the Executive of the Board of Curators and the Executive of the Evangelical Initiative was held on 4 April 2008. At first Prof. Müller, being on the Executive of the Board of Curators representing the lecturers, attended this meeting. However, objections were raised against his presence and he decided to leave the meeting (Kerkbode 06.06.08:3). The EI distributed their own one-sided account of this preliminary meeting. Later that year both the chairperson and secretary of the EI resigned. Since then Prof. J.W. Hofmeyr has been the chairperson (Kerkbode 15.08.08:3, 05.09.08:5)

\section{THE FUTURE}

The need for theological training in Pretoria arose when it became clear that a large proportion of DRC members settled in the north of South Africa. The intention to house theological training at a university and not at a separate Seminary was not based solely on financial factors. Since the beginning theological training was intended to be part of a scientific approach.

Healthy friction between Church and theological seminary is necessary. History proves that one of the problems that were foreseen with a theological Faculty, namely the possibility that heterodoxy would gain momentum, is untrue. There are enough measures within the Church polity to prevent this from happening.

Many challenges remain for both Faculty and Church. The bond between Church and Faculty should be strong in order to overcome those challenges. In these trying times the Church should continue to seek the best theological training for its students in order to be a thriving Church. This should be done honestly, earnestly and faithfully. As long as the University provides the opportunity for this to be attained the DRC should seek to make the best use of the opportunity.

\section{REFERENCES}

Borchardt, C.F.A., 1988, 'Fakulteit en Kerk' in P.B. van der Watt, Deo Gloria! Teologiese Fakulteit 1938-1988, n.p., Pretoria, NGKB.

De Villiers, J., 2005, 'NG teoloë frons oor student se aanval op hul "opstandingsdwalings"', Die Burger, 25 June, p. 7.

De Villiers, J., 2005, 'Studente keer protesbrief teen teoloë die rug toe', Die Burger, 27 June, p. 9.
De Villiers, J., 2005, 'Hulle het nie brief geteken, sê 7 van UP', Beeld, 27 June, n.p.

De Villiers, J., 2005, 'Drie Tukkie-teoloë gooi wal oor Jesusopstanding', Die Burger, 2 July, p. 6.

De Villiers, J., 2005, 'Dwaalleer'-brief gekap', Beeld, 5 July 2005, n.p.

De Villiers, J., 2005, 'Vals persepsies' naamskending, sê 3 teoloë', Die Burger. 5 July, n.p.

Du Toit, F., Hofmeyr, H., Strauss, P. \& Van der Merwe, J., 2002, Moeisame pad na vernuwing: Die NG Kerk se pad van isolasie en die soeke na nuwe relevansie 1974-2002, Bloemfontein, CLF.

Hofmeyr, H., 2008, 'Klonkies en Kabouters' en die gekweste hart van die Evangelie', Beeld, 6 July, p.6.

Jackson, N., 2004, 'As homoseksualiteit nie sonde is nie, hoe word hulle verlos?', Beeld, 7 December, p. 9.

Jackson, N., 2005, 'Kweekskole sê dosente kry onregverdig liberalisme-etiket', Beeld, 13 June, n.p.

Jackson, N., 2005, 'NGK wil sy vertroue wys in UP-dosente', Beeld, 23 July, p. 5.

Jackson, N., 2005, 'Kuratorium soek regsraad in UP-kwessie', Beeld 14 August, n.p.

Jackson, N., 2006, 'Teologiestudent skuldig aan oneerlikheid oor dwaalleer-brief', Beeld, 29 March, n.p.

Jackson, N., 2006 'Gekeer om te studeer', Beeld, 22 December, n.p.

Malan, M., 2005, 'Aparte Kweekskool beplan', Rapport, 22 May, n.p.

Malan, M., 2005, 'Kuratoria steun teologiedosente', Rapport, 12 June, n.p.

Maritz, P.J., 2003, 'Ben Marais (1909-1999): The influence on and heritage of a South African prophet during two periods of transformation', DD dissertation, Department of Church Polity and Church History, University of Pretoria.

Müller, J., 2006, Opstanding, Wellington, Lux VerbiBM.

Nicol, W., 1934, 'Wat die Kweekskool vir die Transvaal beteken het', in Gedenkboek van die Teologiese Seminarie (N.G. Kerk) Stellenbosch - Driekwart Eeufees 1859-1934, Pro Ecclesia Printers, Stellenbosch.

Nicol, W. (ed.), 1946, Die ontstaan en groei van ons Teologiese Fakulteit en huldebetoon aan die grondlegger Prof GM Pellissier,Voortrekkerpers, Pretoria.

Nicol, W., 1958, Met toga en troffel, NG Kerk Uitgewers, Cape Town.

'Nuwe' strominge in die teologie. Word die hart van die evangelie uitgeruk?, 2007, DVD, WTL Produksies (Krugersdorp).

Rabie, J., 1934, 'Die toekoms van ons Kweekskool', in Gedenkboek van die Teologiese Seminarie (N.G. Kerk) Stellenbosch-Driekwart Eeufees 1859-1934, Pro Ecclesia Printers, Stellenbosch.

Rossouw, J., 2005, 'Opstand in die NG Kerk', Die Vrye Afrikaan, 19 Aug., n.p.

Serfontein, J.H.P., 1982, A partheid, change and the NG Kerk, Taurus, Emmerentia.

Smith, N.J., Geldenhuys, F.E. O'B. \& Meiring, P., 1981, Stormkompas. Opstelle op soekna'n suiwer koers in die Suid-Afrikaanse konteks van die jare tagtig, Tafelberg, Kaapstad.

Van der Merwe, J.M. \& Vos, C.J.A., 2009, The history of the Faculty of Theology at the University of Pretoria: A Dutch Reformed perspective 1938-2008, Verbum et Eclessia 30(3).

Van der Watt, P.B., 1987, Die Nederduitse Gereformeerde Kerk 19051975, Deel Vier, NGKB, Pretoria.

Van der Watt, P.B. (ed.), 1988, Deo Gloria! Teologiese Fakulteit 1938-1988, NGKB, Pretoria.

Van der Watt, P.B., 2008, Tukkies oorskou sy eerste honderd jaar 1908-2008, Business Print, Pretoria.

Vos, C., 2008, 'Te veel sout en peper in die gereg', Beeld, 13 September 2008, p. 3.

\section{Archival sources:}

Acta Nederduitsch Hervormde of Gereformeerde Kerk van Zuid-Afrika, 1916.

Acta Nederduitsch Hervormde of Gereformeerde Kerk van Zuid-Afrika, 1934 
Acts Synod Eastern Transvaal, 2005.

Acts General Synod, Dutch Reformed Church, 2007

Agenda Synod Eastern Transvaal, 2007.

Official Guard Book of the Board of Curators in Pretoria.

\section{Periodicals:}

Kerkbode (previously known as Die Kerkbode)

15.06.1916: 580; 30.03.1922: 411; 20.04.1922: 496-497;

27.04.1922: 547; 25.04.1934: 746;

06.06.1934: 1046-1048; 08.07.2005: 3; 14.04.2006: 5 ;

13.10.2006: 6; 26.01.2007: 5; 10.08.2007: 3; 24.08.2007: 3;

14.09.2007: 5; 08.06.2007: 3; 27.07.2007: 3; 12.10.2007: 1 ;

06.06.2008: $3 ; 15.08 .2008: 3$.

Die Volksblad: 22.06.2005.

\section{Webpages:}

http://www.teo.co.za (Accessed 18 November 2009)

www.teo.co.za/wmview.php?ArtID=302

PR du Toit, Minister for Theological Training. March 2006.

Title: 'Persverklaring'. Regarding the Disciplinary Hearing of Mr F.S. Mulder.

www.teo.co.za/wmview.php?ArtID=571
Original Statement by DR lecturers, dated 24 April 2002.

Title: 'Verklaring Dosenteraad (2002): 'n Openbare getuienis'.

www.teo.co.za/wmview.php?ArtID=572

Statement by DR Board of Lecturers. Title: 'Verklaring

Dosenteraad (2007): Teologiese Strominge'. Dated 2.08.2007

www.teo.co.za/wmview.php?ArtID=575

Julian Müller's reaction on DVD. Title: 'Reaksie op DVD: 01'.

www.teo.co.za/wmview.php?ArtID=576

Dirk Human's reaction on DVD: Title: 'Reaksie op DVD: 02'.

www.teo.co.za/wmview.php?ArtID=577

Jurie le Roux's reaction on DVD. Title: 'Reaksie op DVD: 03'.

www.teo.co.za/wmview.php?ArtID=578

Letter Prof AG van Aarde. 15.08.2007 Title: 'Reaksie op DVD: $04^{\prime}$.

www.teo.co.za/wmview.php?ArtID=579

Statement: PR du Toit on behalf of the Curatorium

15.08.2007. Title: 'Verklaring Kuratorium'. 